\title{
CEsifo \\ WORKING

\section{Political Competitiveness and Fiscal Structure: A Time Series Analysis. Canada, 1870 - 2015}

J. Stephen Ferris, Stanley L. Winer 


\section{Impressum:}

CESifo Working Papers

ISSN 2364-1428 (electronic version)

Publisher and distributor: Munich Society for the Promotion of Economic Research - CESifo $\mathrm{GmbH}$

The international platform of Ludwigs-Maximilians University's Center for Economic Studies and the ifo Institute

Poschingerstr. 5, 81679 Munich, Germany

Telephone +49 (o)89 2180-2740, Telefax +49 (o)89 2180-17845, email office@cesifo.de

Editors: Clemens Fuest, Oliver Falck, Jasmin Gröschl

www.cesifo-group.org/wp

An electronic version of the paper may be downloaded

- from the SSRN website: $\quad$ www.SSRN.com

- from the RePEc website: $\quad$ www.RePEc.org

- from the CESifo website: www.CESifo-group.org/wp 


\title{
Political Competitiveness and Fiscal Structure: A Time Series Analysis. Canada, 1870 - 2015
}

\begin{abstract}
We investigate the extent to which the intensity of political competition moderates the governance issues that arise in relation to Canada's fiscal structure. By fiscal structure we mean three distinct but interrelated fiscal dimensions of the state: financial stability, long run size and short run interventions into the private economy with respect to the business cycle. The paper is distinctive in focusing on four measures of political competitiveness that reflect the degree of competition in and between national parliamentary elections: the size of the majority of the governing party in the House; the distribution of the volatility adjusted winning margins of the governing party; the proportion of electorally marginal constituencies adjusted for asymmetry between parties; and a multiparty measure of the competitiveness of elections at the constituency level. The analysis accounts for the differing time series properties of the political and economic variables and the comingling of long and short term fiscal policies in the time series data. Estimation using a sequence of ARDL models indicates that greater political competition enhances fiscal stability, speeds up convergence of government size from above on fundamentals, and helps to align fiscal deficits better with the business cycle. The potential quantitative impact of more intense electoral competition is analyzed by applying the deficit model to the period of fiscal instability that arose in the 1980's and early 1990's.
\end{abstract}

JEL-Codes: D720, D780, H300, H500.

Keywords: political competition, electoral competition, fiscal stability, budget composition, expenditure and tax size, debt and deficits, countercyclical policy, ARDL modeling.

\author{
J. Stephen Ferris \\ Department of Economics \\ Carleton University / Ottawa / Canada \\ steve.ferris@carleton.ca
}

\author{
Stanley L. Winer* \\ School of Public Policy and Administration \\ \& Department of Economics \\ Carleton University / Ottawa / Canada \\ stanley.winer@carleton.ca
}

July 31, 2018

An earlier version of this paper was given at the Canadian Economic Association Meetings in Montreal, June 2018. The empirical work in our political competition project would not have been possible without the ongoing support of a number of research assistants. Those particularly relevant to this paper are: Derek Olmstead, Beatriz Paraza Lopez, Samira Hasanzadeh and Jérôme Archambault. Their help in compiling the electoral data and coding the Stata programs underlying the derivation of the competitive indices is greatly appreciated. 


\section{Introduction}

This paper is concerned with the role played by political competition in moderating a set of governance issues that arise in relation to a country's fiscal structure. By fiscal structure we mean three distinct but interrelated fiscal dimensions of the state: its financial stability (can it pay its bills?), its long run size (does it produce what the community wishes?) and its short run interaction with the private economy in response to the business cycle (can it minimize the business cycle?). Governance issues arise in relation to these policy objectives because under representative government, and particularly in a Westminster parliamentary system such as Canada's, the governing political party stands as the agent that makes and implements the fiscal decisions desired by its principal, the electorate. Because the interests of the political party are not coincident with the interests of the electorate, the cost of motivating, monitoring and enforcing the governing party to act in the best interests of the electorate allow for the existence of agency problems.

Political competition works to moderate governance issues by requiring political parties to compete in regular elections whose outcome allocates the right to govern to the party whose promised policies best reflect the wishes of the electorate. As importantly, however, political party competitors are the actors that can best assess the feasibility of election promises and the effectiveness of their implementation. Their ability to benefit electorally by transmitting their knowledge of shortfalls in performance to the electorate helps align governing behaviour more closely with election promises. From the governing party's perspective, the ability to fulfill its election promises establishes credibility and allows the party to benefit through the formation of reputation or a brand name. Finally, competition among the parties at the constituency level works to minimize the governing party's own agency problem. The more that individual candidates need to rely on the support of their party in tightly contested races, the greater is the party's ability to overcome the incentive individual members have to pursue personal or constituency specific benefits at the cost of the party and general community.

The consequences of a change in the scale of political competition become observable in a number of ways. For example, the shortness of election terms and active political lives encourages decision makers to spend now and postpone the political cost of higher taxes until later through borrowing. A reduction in political competition then means that short run deficits will be opposed less effectively permitting a drift towards higher debt levels and the potential for fiscal instability. Similarly, a lack of political competition reduces the monitoring of government program spending, allowing the governing party to appropriate higher rents. This in turn results in a government size that is larger than that wished by the electorate. Less political competition also reduces the ability of the political process to deal effectively with the business cycle. The difficulty of knowing exactly what the government could have done in response to the 
business cycle increases with a fall in political competition and allows the governing party to become less vigilant in its monitoring of and response to the business cycle.

Because the structural elements of fiscal policies are interrelated, longer run equilibrium relationships, the ability to test fiscal hypotheses within a single country requires the data to satisfy special conditions and the analysis to overcome complex identification issues. Perhaps most obviously, focus on a single country requires long time series of reliable data, generated within an institutional environment that has remained fundamentally unchanged for the period under investigation. With a considerable amount of reliable long run data generated within a stable political environment, Canada--from its emergence as a modern state at Confederation (1867) to the present-satisfies this necessary condition. ${ }^{2}$ The Canadian data used in this paper are annual and run for one hundred and forty-five years from 1870 through 2015.

A second issue is that the observable outcomes of the different policies that comprise a country's fiscal structure are all embodied in the same set of time series. That is, the long run empirical relationships that describe both Canada's history of financial stability and government size are the same data series that incorporate Canada's history of countercyclical fiscal response. This comingling of policy outcomes means that the long and short run hypotheses that explain fiscal policy choices need to be modeled and tested together. This challenge presented by the data motivates the sequencing of our tests and the use of cointegration and error correction analysis.

A third feature of the data that complicates the political dimension of fiscal issues is that the metrics used to proxy economic and political processes often have different time series properties. In particular many measures of political/electoral competition are stationary while most economic variables are not. Hence care must be taken with how the differing time series dimensions of the economic and political variables are combined. This feature of the data led us to adopt the autoregressive distributed lag (ARDL) procedure developed by Pesaran, Shin and Smith (2001) that allows for the combination of variables with different degrees of integration and provides a separation of long and short run effects. A complete list of variables used, their descriptive statistics and time series properties is included in the Data Appendix of this paper.

Finally, while many authors test for the effects of political competition by using a single metric (such as the number of political parties or the size of the winning vote margin), we view political competition as inherently multidimensional in nature. In general, the competition faced by an incumbent governing party can be thought of as arising from actual or potential entrants, from existing parties active

\footnotetext{
${ }^{2}$ Even so availability remains an issue. Unemployment figures, for example, are available in Canada only from 1919 onwards so that for the longer run, business cycles are measured in terms of variations in output growth rates.
} 
in the upcoming election, from elected parties present in the House during the governing period, and from other governing parties at the same or different levels of government. Moreover, each of these levels of competition presents multiple directions from which the behaviour of the governing party is constrained. In this paper we restrict our analysis to two of these four categories and hence to variations in what we call electoral competition - the degree of competition arising among parties in the upcoming election and the intensity of competition among elected parties following the election. ${ }^{3}$

The paper proceeds in Section 2 with a short survey of the literature explaining how electoral competition is expected to affect fiscal stability and government size, and what set of measures will be used to proxy these elements of electoral competition. Section 3 tests for fiscal stability by considering the evolution of deficits and public debt, first as a test without asking how the observed degree of stability is achieved. We then ask whether there is evidence of fiscal stability having been influenced by political competitiveness. Section 4 uses a set of economic and demographic fundamentals to explain the long run expenditure and tax sizes of government together with the indexes of competition between and in elections. Section 5 focuses on the question of whether electoral competition has influenced the countercyclical behavior of the deficit. Section 6 applies the model to the period of rapid federal debt accumulation from the mid-1970s to the early 1990s, considering the performance of political competition throughout the period, and illustrating how even minor changes in the intensity of political competition could have altered the overall outcome in a desirable direction. Section 7 concludes by summarizing the policy significance of our results.

\section{A principal-agent approach to fiscal structure}

The analysis uses a principal-agent approach to the performance of a single member, first-past-the-post Westminster style parliamentary democracy and applies that analysis to Canada, a country with a fundamentally unchanged governance structure since its founding in $1867 .{ }^{4}$ In such a setting, the governing party is viewed as the agent representing the public as its principal, much as the board of directors serves as the agent for a firm's shareholders. The central problem is to control the agent. Persson, Roland and Tabellini (2000) see this problem of governance as arising out of three fundamental characteristics of modern systems of representative self-government: no direct democracy, no benevolent actors, and no outside enforcement. The analysis we develop in this paper focuses on the extent to which enforcement or policing of the behavior of the agent - the government in a Westminster parliamentary democracy - is

\footnotetext{
3 For an analysis of fiscal issues arising among Canadian provinces and between the federal and provincial level of government in Canada see Kneebone and McKenzie (1999). On party entry and exit, see Ferris and Voia (2018).

${ }^{4}$ Elements of this approach are found in many places in the public choice literature. See for example, Persson et al 2000, and Ashworth et al 2014.
} 
provided by competition among political parties and candidates. In much of the principal-agent, political economy literature, the agency problem is posed as a question about whether or not the individual members of Congress vote differently from the wishes of their electorate (e.g., Higgs, 1989; Bender, 1994; Jung, Kenny and Lott; 1994). Here complications in defining authority arise because the checks and balances that are part of the Congressional system diffuse responsibility for policy action. In the Westminster parliamentary system of Canada, however, the executive and legislative branches are combined, and the governing party determines policy subject to its ability to maintain the confidence of the House of Commons. The party winning the election is the main agent that monitors and enforces the behaviour of its representatives while setting the overall policy agenda for government. Moreover, the long life of the major political parties allows for the development of reputation which in turn serves as a commitment mechanism to help internalize intertemporal externalities.

In this type of democracy, then, parties compete to win the right to govern by promising and delivering programs that better reflect the wishes of voters, more or less as Demsetz's potential managers compete for the right to become the sole operator of a natural monopoly in a private market (Demsetz, 1968; Palmer, 1995). ${ }^{5}$ It follows that in the absence of information and other coordination costs, and with open entry into the political arena, competition among political parties would result in the government providing the low cost program mix that best reflects the wishes of its constituents. ${ }^{6}$

In real world situations information and coordination costs are never zero. The ability to organize a viable political party requires the party to attract and maintain the loyalty of members who typically join for reasons that are not coincident with the program wishes of the public. The party must then provide partisans with special benefits, perhaps in the form of positions in the new government or programs that cater to their special interests. It follows that the incumbent governing party will normally provide a mix of government services directed at the preferences of both the electorate and their own partisan members. In the political science literature this is described as governments having to provide a mix of 'public' goods and 'private' benefits. (See for example, Bueno de Mesquita et al, 2008). But while all political parties must provide for its supporters in one way or another, the ability of the party to cater to such special interests at the expense of, or in addition to, the more general interests of the public will depend on the degree of competition provided by opposition parties. In the empirical work, we allow for

\footnotetext{
${ }^{5}$ Demsetz's approach leads to efficiency even with one 'firm' because he expands the margins along which performance can be specified. In the political context, meaningful forcing contracts must permit effective enforcement of multidimensional campaign promises. See the more extended discussion of the application of Demsetz's approach in Ferris, Winer and Grofman (2016).

${ }^{6}$ This does not mean that all citizens are treated equally. Political influence matters. By 'best, we mean that there are no Pareto efficiency gains to be had in equilibrium (in the strongest form of this view.)
} 
the presence of partisanship in an electoral equilibrium - the catering to special interests allied with governing parties. However, our primary focus remains on the role of competition.

To capture variations in the intensity of political competition both in and between elections we focus on four dimensions or types of competition underlying the political process, consider their role in dealing with the agency problem and outline the potential consequences of weakening each dimension for fiscal policy choices. ${ }^{7}$ The discussion of the indexes is informal with more formal definitions provided in the Appendix.

First, the ability of a political party once elected to cater to its own partisan interests will depend in part on how effectively they are policed by members of the other elected parties. ${ }^{8}$ Between elections, this control will depend in part on the proportion of the seats controlled by the governing party. The smaller is the opposition in the House between elections, the less effective can competing parties be in monitoring the behavior of the party in power and hence the less costly it will be (in terms of lost political support) for the party in power to provide its members with specialized 'private' benefits. (See also Rogers and Rogers, 2000). The relative size of the government's majority, denoted LNSEATS in the statistical tables below, is used as measure of the government's effective control over Parliament, with a larger realized majority implying that the opposition parties in Parliament are less effective in helping to maintain the fiscal discipline needed to restrain government spending. To the extent that payment for these expenditures can be transferred through time to a succeeding government, it also implies a larger sized deficit.

In addition to the size of the majority held by the governing party, the unity of the caucus of elected government members will also matter for its policy choices between elections (Aldrich and Rohde 2000, Aldrich et al 2007, Winer et al 2008). The greater is the heterogeneity of interests within the party, especially with respect to national versus local issues, the less willing will members be to effectively delegate decision making power to, and accept constraints from, the national party leader. Heterogeneity of this kind makes it harder for the party to maintain a common set of programs on difficult issues like restraining spending and/or raising taxes, thereby moderating the common pool problem that arises in an electoral system based on geographically defined constituencies, where it is always in the narrow selfinterest of elected members to deliver benefits to his or her constituents with taxes levied on taxpayers in

\footnotetext{
${ }^{7}$ Most tests for the effects of political competition use only one measure, such as vote shares (Holbrook and Van Dunk, 1993), vote shares relative to some norm such as $1 / 2$ (Besley et al, 2010), or the number of political parties (Lizzeri and Persico, 2005). Skilling and Zeckhauser (2002) use a competition index defined as $1-\sum \alpha_{i}^{2}$ where $\alpha_{i}$ is the proportion of time in office for party (coalition) i. A recent exception is Ashworth, Geys, Heyndels and Wille (2014) who use two competition measures - the number of parties and the volatility of electoral outcomes.

${ }^{8}$ Question period and unrestricted access to the press are two channels by which insider information can be transmitted to voters allowing political competition to constrain partisan behavior.
} 
the country as a whole. ${ }^{9}$

The measure of party unity we use to investigate the fiscal consequences of party unity is the coefficient of variation of the volatility adjusted, first versus second place winning vote share margins of elected members of the governing party, $C V \_$winmargin. Here the winning vote share margin of each elected member is adjusted by a measure of the number of voters in the relevant constituency who have switched their vote in the current election compared to the last, because the effective size of a given margin depends on how volatile the local electorate is. (Even a 'large' winning margin can be effectively small if the relevant electorate is highly volatile.) Higher values of $C V_{-}$winmargin are assumed to imply greater diversity of political incentives of elected members, higher costs of coordinating joint action, and thus less control by the government over its elected members. In turn, this implies higher levels of spending and lower taxation to cater to the interests of a less unified or less controllable caucus, and less of a concern with fiscal stability.

In addition to the size and cohesiveness of the governing majority, the nature of and credibility of party promises to its partisans and voters in general will depend upon how competitive or contestable the upcoming election is among the major competing parties. More intense competition will engender more fiscal responsibility, and generally constrain the ability of the party to deliver benefits to special interests, thus leading to a better matching of fiscal policy with the underlying interests of the general public. Whether this leads to more or less spending and to higher or lower deficits depends on preferences and the state of the economy. Governments do not lose votes by raising taxes to pay for things people want.

The degree of competition or contestability among major parties in the election is defined as the proportion of constituencies that are 'not safe' for the incumbent, where safe constituencies are ones that lie consistently in the upper tail of the distribution of volatility adjusted winning vote margins of incumbents in previous elections. For each election, we first construct a volatility adjusted, first versus second place winning vote share margin for each incumbent party candidate $p$ (the party $p$ that won in constituency $j$ at time $t-1$ ). If this margin was more than one standard distribution above the mean of all such adjusted winning margins in all constituencies across all parties for the previous three elections, the constituency was judged to be a 'safe' one. ${ }^{10}$ The constituencies considered safe in the next election are constructed in the same way by adding the next election and dropping the oldest of the three to form the

\footnotetext{
${ }^{9}$ On the common pool problem in majoritarian systems, see Tullock (1959) and Buchanan and Tullock (1963). We note also that measurement of party unity will depend on the definition of 'a party'. This matter is dealt with in the Appendix. ${ }^{10}$ Because the construction of volatility requires margin measures from three consecutive past election outcomes, the addition of new ridings as the country grows and periodic redistricting create problems for consistency of measurement over time. To circumvent this problem, we used unchanging geographical areas to define 80 'super-constituencies' across which measures of volatility by party are defined. This feature enters several of our constructs and is discussed more fully in the data appendix.
} 
new test distribution. Applying this algorithm to all constituencies in each election, we find the proportion of all constituencies that are considered to be safe in each election, $\psi_{t}$. The proportion of constituencies that are considered marginal is then $M$ Cons_SD $D_{t}=1-\psi_{t}$.

We next acknowledge the importance of how safe constituencies are distributed across the parties by adjusting the proportion of marginal seats for the degree of their asymmetry among the parties, using a Euclidean measure of the deviation of the proportion of safe constituencies from a three party equal sharing norm, $\phi_{t} \cdot{ }^{11}$ A party with a preponderance of safe seats compared to its major opposition has an advantage if only because it can better direct its resources to contests where the outcome is liable to be more easily altered. A final allowance for redistricting, outlined in the Appendix, then produces our measure of contestability of major parties at the national level, $A d j_{-} A M C o n s_{-} S D_{t}=1-\psi_{t} \phi_{t}$.

A second measure of competition in elections reflects competitiveness among candidates at the constituency, rather than at the party level. This index, along with vote volatility, was first proposed by Przeworski and Sprague (1971). It is constructed on the premise that the primary objective of each candidate is to overcome the vote share gap, or 'distance to go', he or she faces to overcome the incumbent. The value for constituency $j$ at time $t$ of this multi-party competitiveness index is constructed as the sum over candidates in the same riding (excluding the winner) at time $t-1$ of: (i) one times the candidate's vote-share weight if the vote gap or distance to go is less than volatility, or (ii) the vote-share weighted value of: one over the volatility adjusted vote share gap when the distance to go is greater than volatility. Thus the index falls as the vote gap the candidate has to overcome rises relative to volatility. The national index is then defined as the sum of each constituency's multi-party index weighted by its vote share in the national total. The result is a metric denoted PS_Hist_Cons, where a value of 1 indicates a fully competitive constituency election - the distances to go of every candidate in every constituency is less than the corresponding vote volatility, while a PS_Hist_Cons $=0$ indicates an election that is completely uncompetitive at the constituency level. ${ }^{12}$ As for the party competition index $A d j \_A M C o n s \_S D$, if voters - the principals - are responsible we can expect that greater political competition at the party and constituency levels will enhance fiscal stability (with respect to deficits and debt), speed up convergence of government size to that determined by economic fundamentals, and help to align deficits better with the business cycle. ${ }^{13}$. The use of historical data to judge the nature of contemporaneous elections is

\footnotetext{
11 The third 'party' in this case is a residual category.

12 Many early constituency elections in Canada featured a winner by acclamation and thus were given a PS $=0$. For more detail on the construction of the PS and volatility indexes see the Appendix and associated web site, www.carleton.ca/winer where the full data set will be posted on publication of the paper.

${ }^{13}$ Use of the suffix 'Hist' is to signal that for the current election, the value of PS_Hist_Cons is defined using data on vote share gaps and volatilities from the previous election. It should also be recalled that the party-based measure $A d j \_A M C o n s \_S D$ is based on volatility adjusted incumbent party margins from elections in the past.
} 
designed to deal with the ex post - ex ante problem in the present context. Ex post, a competitive election from an ex ante viewpoint can be one in which one party wins a large majority. ${ }^{14}$ The four competition indexes are presented in Figures 1 and 2 below. In the figures, as in the later statistical work, LNSEATS and $C V \_$winmargin change discretely at each election interval, while Adj_AMCons_SD and PS_Hist_Cons are interpolated between elections to reflect the ever-changing intensity of competition between the snapshot pictures captured at the time of each election. Table A1 of the Appendix shows the partial correlations arising among our four political competition indexes over the history of the Canadian parliament, revealing them to be positively correlated but not highly so. These are measures of distinct dimensions of political competition. The partial correlations run from a low of 0.054 between LNSEATS and Adj_AMCons_SD to a high of 0.602 arising between PS_Hist_Cons and Adj_AMCons_SD. The other four combinations range between 0.168 and 0.295 .

[Figures 1 and 2 here]

The time series properties of our four measures of political competition together with the economic variables used to represent the fundamentals underlying voter demands and constraints on policy choices (introduced later) are presented in Table A2 of the Appendix. What is important to note is that on the basis of the critical values of the adjusted Dickey-Fuller statistics in that table, most of the economic variables are nonstationary while most political variables are stationary. CV_winmargin is the political variable exception, being nonstationary, while the log of the non-interest deficit (denoted LNDEFICIT) and the rate of real growth in excess of the real rate of interest on public debt (FCOST) are the only two economic variables found to be stationary. None are I(2).

Since the ARDL framework established by Pesaran, Shin and Smith (2001) is designed to assess whether or not a long run cointegration or equilibrium relationship exists among a group of variables when the orders of integration are ambiguous and the sample size is small, it is ideally suited as an estimation technique in the present context. In the next section we use this technique to analyse the effects of the four aspects of electoral competition we have measured on the stability of the Government of Canada's finances over the history of the modern state.

\footnotetext{
${ }^{14}$ A case in point is the 1993 general election, in which the previous Conservative government fell from 169 seats to 2 seats.
} 
Figure 1

Competition in the House, 1870-2015

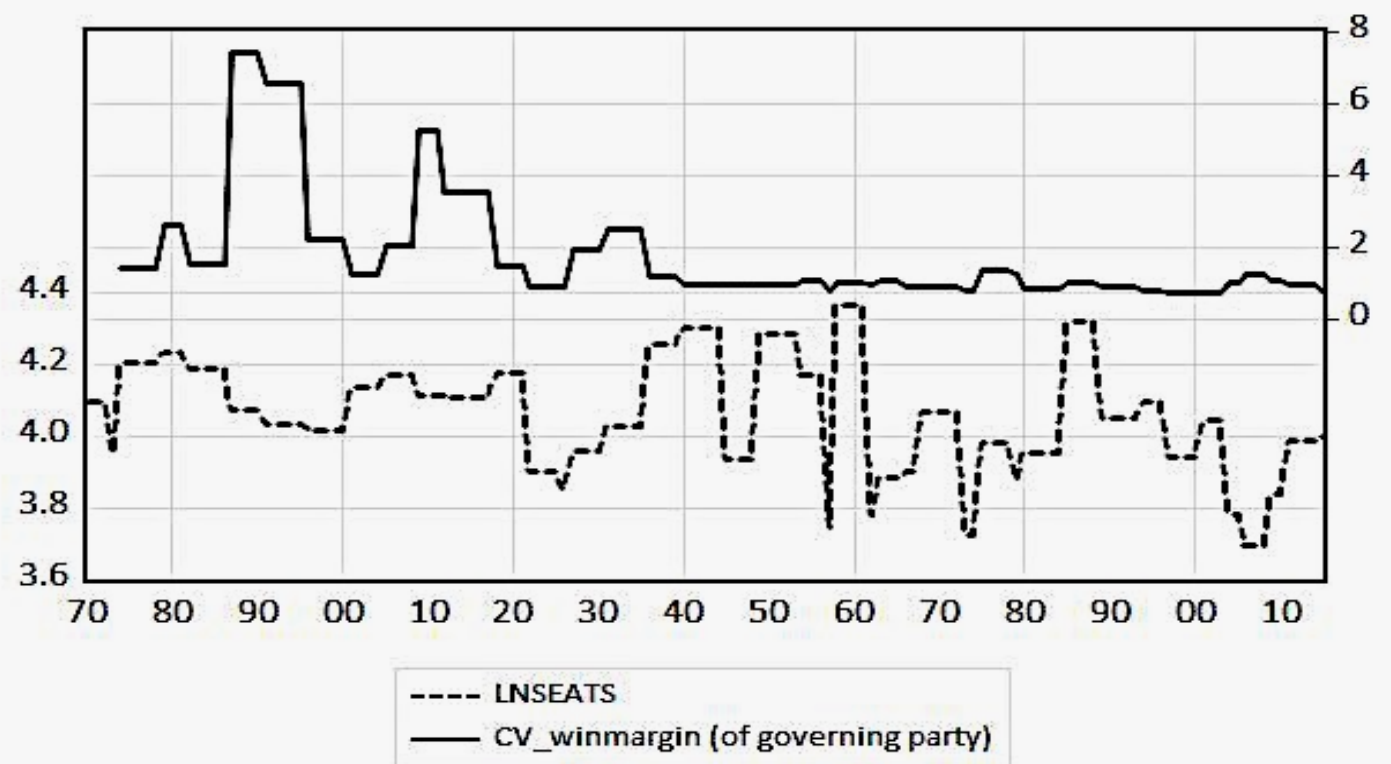

Figure 2

Competition in Elections, $1870-2015$

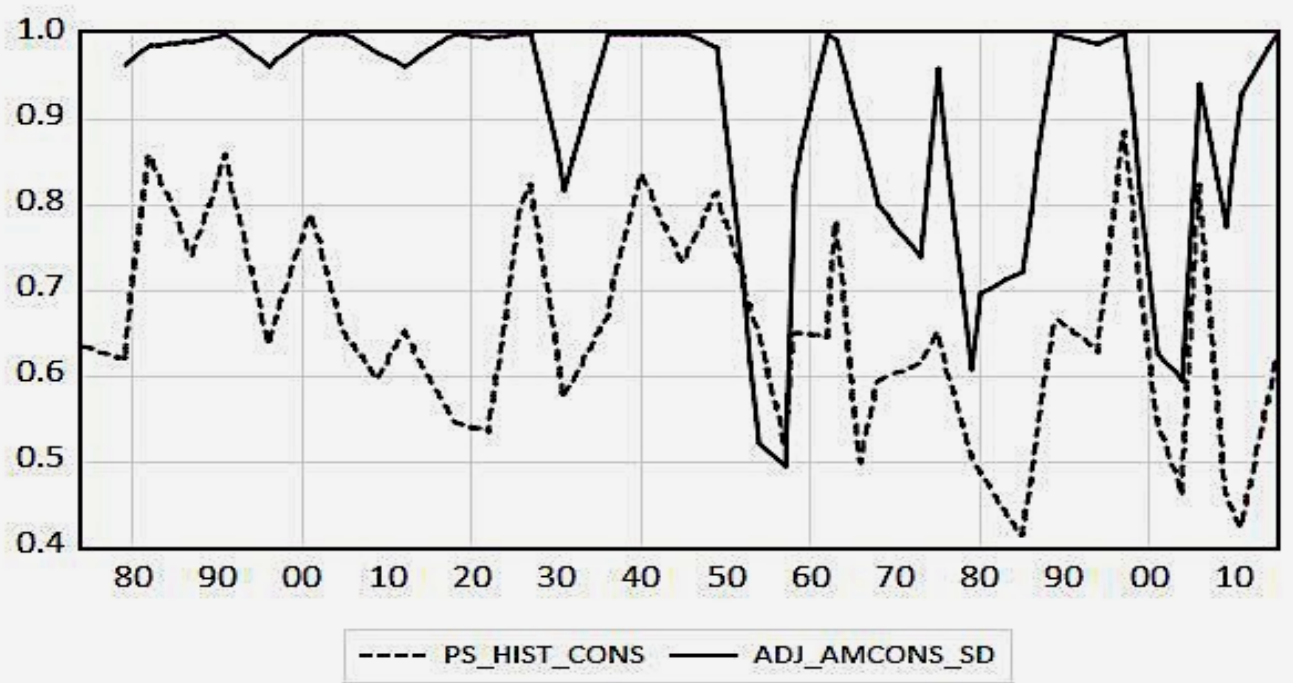




\section{A test for financial stability, and a first look at the role of competition}

By fiscal stability we mean whether the state is financially sound in the sense that expenditures over the longer run are fully funded, so that the long run fiscal objectives of government can be pursued without having to deal with the burden of ever escalating interest payments on government debt. This need not mean that the annual budget is balanced period by period, but rather that over the longer run, expected tax revenues are sufficient to cover planned expenditures.

Canada's history of federal government noninterest spending and tax revenue as a proportion of GDP is presented in Figure 3. Here the primary deficit or surplus appears as the difference between the solid and dashed lines.

Figure 3

Logarithms of Government Expenditure Size, Tax Size and Debt Size (relative to GDP) Canada 1870 - 2011

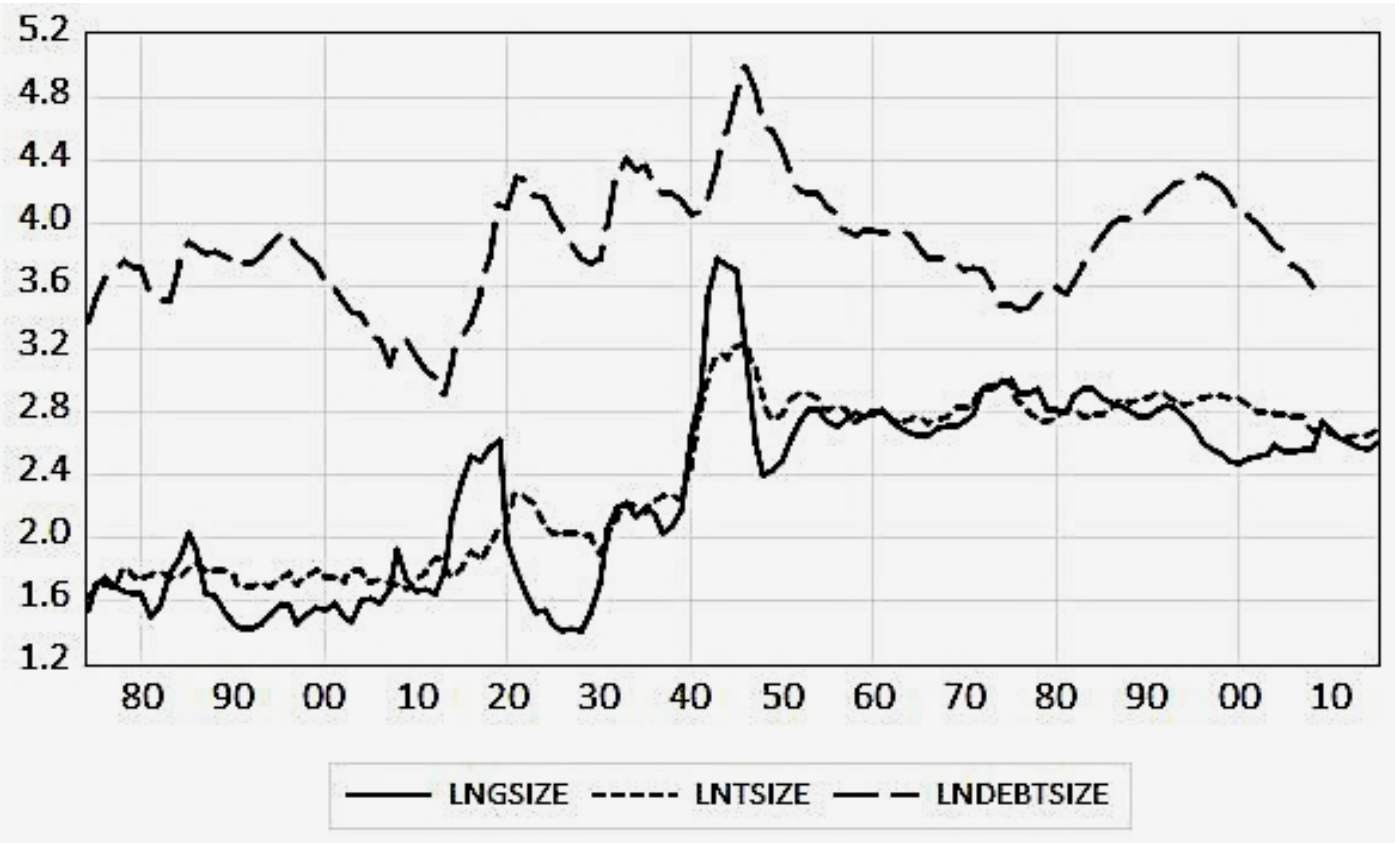

As can be seen from the diagram, deficits have not always been positive, but vary more or less evenly across time. The resulting movement in federal debt as a proportion of GDP appears as the upper dashed line (available only through 2008). Perhaps the most noticeable features of Figure 3 are the episodes in which federal debt has experienced short periods of rapid acceleration. Understandably, the first set of episodes is associated with the extra-ordinary expenditures incurred to fight the two world wars and the Great Depression. In these cases, debt re-payment was spread over time, typically over as long as the following decade. The second striking case is the build-up of federal debt leading into the debt crisis of the mid 1990's. This episode is discussed at length in Section 6 of the paper. From the perspective of 
Canada's entire one hundred and forty five year history, however, the diagram suggests that while federal government deficits and debt levels have risen and fallen over time, neither series shows signs of continual upward drift. ${ }^{15}$

A more formal test of the long run stability of Canadian public finances can be constructed from the definition that the level of federal debt in an economy is sustainable if the share of debt in aggregate income/output, $d_{t}$, does not grow through time (i.e., if $\frac{1}{d_{t}} \cdot \frac{\partial d_{t}}{\partial t} \leq 0$ ). Hence taking the time derivative of $d_{t}=\frac{D_{t}}{p_{t} y_{t}}$, where $D_{t}$ is the nominal level of government debt, $p_{t}$ is the price level, and $y_{t}$ is the level of real income or output, we find that

$$
\frac{d d_{t}}{d t} \frac{1}{d_{t}}=\left(\frac{d D_{t}}{d t} \frac{1}{D_{t}}\right)--\left(\frac{d y_{t}}{d t} \frac{1}{y_{t}}\right)
$$

where $\pi_{t}$ represents the inflation rate, $\left(\frac{d p_{t}}{d t} \frac{1}{p_{t}}\right)$, and $\left(\frac{d y_{t}}{d t} \frac{1}{y_{t}}\right)$ represents the rate of growth of real output. The first term, $\frac{d D_{t}}{d t}$, is the difference between total government spending and tax revenues, $T_{t}$, where total spending depends upon both program spending, $G_{t}$, and interest on outstanding government debt, $i_{t} D_{t}$. Entering this into (1) and multiplying by $d_{t}$ we then have

$$
\frac{d d_{t}}{d t}=\left(\frac{G_{t}-T_{t}}{Y_{t}}\right)+\left[r_{t}-\left(\frac{d y_{t}}{d t} \frac{1}{y_{t}}\right)\right] d_{t}
$$

where $\left(\frac{G_{t}-T_{t}}{Y_{t}}\right)$ is the operating deficit as a fraction of GDP and $r_{t}$ represents the real rate of interest. From (2) it can be seen that a sufficient condition for $\frac{d d_{t}}{d t}=0$ and the share of government debt in GDP to converge in the long run to a constant, $\bar{d}$, is that a particular relationship must exist among the three variables, GSIZE $=G_{t} / Y_{t}, T S I Z E=T_{t} / Y_{t}$, and the fiscal cost of long run debt, $F C O S T_{t}=\left(\frac{d y_{t}}{d t} \frac{1}{y_{t}}-r_{t}\right) \cdot{ }^{16}$ Intuitively, a positive primary deficit (GSIZE - TSIZE) can be sustained in the long run without increasing the debt to GDP ratio only if the average rate of growth of real output exceeds the long run real cost of holding outstanding debt. In Canada's case, FCOST has been stationary or I(0) over time. This implies that because both GSIZE and TSIZE are nonstationary or I(1), long run fiscal stability requires GSIZE = TSIZE.

\footnotetext{
${ }^{15}$ Note that the appearance of stability or instability can depend upon the time period chosen for analysis. Had the analysis ended in 1992, the answer that follows for Canada's fiscal stability could have been quite different. Section 6 examines the role of political competition in relation to this episode of fiscal instability.

${ }^{16}$ The necessary condition is that the present value of government debt approaches zero over time. The advantage of using this condition is that it yields a more transparent testable hypothesis. See Bohn (1998) for an alternative test that focuses on whether the government surplus changes in such a manner as to correct for, or offset increases in government debt.
} 
The sufficient condition for the long run sustainability of government debt can then be operationalized by taking a Taylor Series expansion of (2) about $\bar{d}$ and estimating an ARDL model of the form:

$$
\operatorname{Ln}\left(\frac{G}{Y}\right)_{t}=\alpha_{0}+\sum_{i=1}^{i=n} \alpha_{i t}\left(\frac{G}{Y}\right)_{t-1}+\sum_{j=1}^{j=n} \alpha_{j t}\left(\frac{T}{Y}\right)_{t}+\sum_{k=1}^{k=K} \sum_{i=1}^{i=n} \alpha_{k t} X_{t}+u_{t}
$$

where $n=4, u_{t}$ is a while noise random variable and, in anticipation of the test for the role of electoral competition that will follow, $X_{t}$ is the vector of the electoral competition variables discussed above. The sufficient condition for long run fiscal sustainability, that the debt to income ratio not grow over time, is that $c_{1}=1$ and that the regression residuals in (3) are stationary. With FCOST stationary, $c_{0}=0$ is consistent with $d_{t}$ remaining a long run constant. Note that the stationarity of FCOST means that variations produce transitory effects on the relationship between government expenditure and tax size but have no permanent or long run effect. Hence the effect of FCOST, if any, should show up in the short run or error correction level of analysis (as it does).

The set of ARDL models implied by (3) is estimated using the Schwarz criterion to select the optimal lag length for each of the model's variables (up to a maximum of 4 lags per variable). ${ }^{17}$ The optimal ARDL model found on this basis is presented in Table 1. The full ARDL model is presented in column (1). Using period dummies to offset a number of war related outliers, the ARDL equation passes two stability tests: the cumulative sum of recursive residuals (CUSUM) and the cumulative sum of squares (CUSUM of Squares). In each case the recursive sums remain within the 5 percent bounds. The value found for the Bounds test (8.81), presented in the bottom line of column (2), implies that the long run equation is consistent with cointegration arising among the I(1) variables and thus with the existence of a long run equilibrium relationship. The short run process is presented in column (3) together with the error correction term. The latter is significantly negative but small in size, confirming convergence while indicating that the speed of that convergence is relatively slow.

[Table 1 here]

${ }^{17}$ Estimation uses the ARDL module in Eviews 10. 
Table 1

ARDL Models of Fiscal Stability, Canada 1870 - 2015

(Newey West standard errors in brackets; lags selected using the Schwarz criterion)

\begin{tabular}{|c|c|c|c|c|c|c|}
\hline $\begin{array}{c}\text { Equation Type } \\
\text { Dependent Variable }\end{array}$ & $\begin{array}{c}\text { (1) } \\
\text { ARDL } \\
\text { Equation }^{\mathrm{t}} \\
(2,1,1) \\
\text { LNGSIZE }\end{array}$ & $\begin{array}{c}\text { (2) } \\
\text { LONG } \\
\text { RUN } \\
\text { LNGSIZE }\end{array}$ & $\begin{array}{c}\text { (3) } \\
\text { SHORT RUN } \\
\text { and ERROR } \\
\text { CORRECTION } \\
\text { D(LNGSIZE) }\end{array}$ & $\begin{array}{c}(4) \\
\text { ARDL WITH } \\
\text { COMPETITION }^{t} \\
(2,0,1,0,0,0) \\
\text { LNGSIZE }\end{array}$ & $\begin{array}{c}(5) \\
\text { LONG RUN } \\
\text { WITH } \\
\text { COMPETITION } \\
\text { VARIABLES } \\
\text { LNGSIZE }\end{array}$ & $\begin{array}{c}\text { (6) } \\
\text { SHORT RUN } \\
\text { WITH } \\
\text { COMPETITION } \\
\text { VARIABLES } \\
\text { D(LNGSIZE) }\end{array}$ \\
\hline LNGSIZE(-1) & $\begin{array}{c}1.328^{* * *} \\
(0.085)\end{array}$ & & & $\begin{array}{c}1.348^{* * *} \\
(0.061)\end{array}$ & & \\
\hline LNGSIZE(-2) & $\begin{array}{c}0.513^{* * *} \\
(0.068)\end{array}$ & & & $\begin{array}{c}-0.533^{* * *} \\
(0.051)\end{array}$ & & \\
\hline D(LNGSIZE(-1)) & & & $\begin{array}{c}0.513 * * * \\
(0.050)\end{array}$ & & & $\begin{array}{c}0.533 * * * \\
(0.039)\end{array}$ \\
\hline LNTSIZE & $\begin{array}{l}0.446^{* *} \\
(0.203)\end{array}$ & $\begin{array}{c}1.00^{* * * z} \\
(0.060)\end{array}$ & & $\begin{array}{c}0.174 * * * \\
(0.040)\end{array}$ & $\begin{array}{c}0.942 * * * \mathrm{Z} \\
(0.081)\end{array}$ & \\
\hline LNTSIZE(-1) & $\begin{array}{l}-0.261 \\
(0.182)\end{array}$ & & & & & \\
\hline D(LNTSIZE) & & & $\begin{array}{c}0.446^{* * *} \\
(0.108)\end{array}$ & & & \\
\hline FCOST & $\begin{array}{c}0.007 * * * \\
(0.002)\end{array}$ & $\begin{array}{l}-0.001 \\
(0.005)\end{array}$ & & $\begin{array}{c}-0.007^{* * *} \\
(0.001)\end{array}$ & $\begin{array}{l}-0.003 \\
(0.005)\end{array}$ & \\
\hline $\mathrm{FCOST}(-1)$ & $\begin{array}{c}0.006^{* * *} \\
(0.002)\end{array}$ & & & $\begin{array}{c}0.007^{* * *} \\
(0.001)\end{array}$ & & \\
\hline $\mathrm{D}(\mathrm{FCOST})$ & & & $\begin{array}{c}-0.006^{* * *} \\
(0.001)\end{array}$ & & & $\begin{array}{c}-0.007^{* * *} \\
(0.001)\end{array}$ \\
\hline LNSEATS & & & & $\begin{array}{l}0.048 ? \\
(0.031)\end{array}$ & $\begin{array}{l}0.261^{?} \\
(0.170)\end{array}$ & \\
\hline CV_winmargin & & & & $\begin{array}{l}-0.003 \\
(0.004)\end{array}$ & $\begin{array}{l}-0.015 \\
(0.021)\end{array}$ & \\
\hline \multicolumn{7}{|l|}{ Adj_AMCons_SD } \\
\hline PS_Hist_Cons & & & & $\begin{array}{c}-0.118^{* *} \\
(0.047)\end{array}$ & $\begin{array}{c}-0.640^{* *} \\
(0.262)\end{array}$ & \\
\hline CONSTANT & $\begin{array}{l}-0.017 \\
10.028\end{array}$ & $\begin{array}{l}-0.090 \\
(0.147)\end{array}$ & & $\begin{array}{l}-0.105 \\
(0.146)\end{array}$ & $\begin{array}{l}-0.568 \\
(0.779)\end{array}$ & \\
\hline $\begin{array}{r}\begin{array}{r}\text { Error correction } \\
\text { term }\end{array}\end{array}$ & & & $\begin{array}{c}-0.185^{* * *} \\
(0.031)\end{array}$ & & & $\begin{array}{c}-0.185^{* * *} \\
(0.027)\end{array}$ \\
\hline $\begin{array}{r}\text { Bounds Test } \\
\text { Critical upper bound }\end{array}$ & \multicolumn{3}{|c|}{$\begin{array}{c}8.81^{* * *} \\
I(1,142) \text { at } 1 \%=5.393\end{array}$} & \multicolumn{3}{|c|}{$\begin{array}{c}6.55^{* * *} \\
I(1,142) \text { at } 1 \%=4.59\end{array}$} \\
\hline Observations & \multicolumn{3}{|l|}{142} & \multicolumn{3}{|l|}{142} \\
\hline $\operatorname{Adj} R^{2}$ & \multicolumn{3}{|l|}{0.984} & \multicolumn{3}{|l|}{0.988} \\
\hline
\end{tabular}

Notes: ${ }^{*}\left({ }^{* *}\right)[* * *]$ significantly different from zero at $10 \%(5 \%)[1 \%] .{ }^{2}$ insignificantly different from 1 at $1 \%$; ${ }^{\mathrm{t}}$ Recursive residuals pass the CUSUM and CUSUM of Squares tests at $5 \%$. ? indicates near significance at the 10\% level (12\%). The equations include dummy variables for WW1, 1920, 1940, 1942 and 1946 (discrete changes in spending about the world war years). 
The coefficient estimates of the long run cointegrating equation in column (2) meet the sufficient condition for long run fiscal sustainability in Canada. The coefficient estimate on LNTSIZE is 1.002, insignificantly different from 1, while the coefficient on FCOST and the regression constant are both insignificantly different from zero. Together these results imply the existence of fiscal stability in Canada that federal government deficits are stationary and that its debt as a fraction of GDP has not increased significantly over the entire post-Confederation time period.

The short run is also informative. While FCOST has no long run effect on the growth rate of government debt, column (3) indicates that changes in FCOST are highly significant in the short run, as we expect. That is, transitory increases in the real rate of growth relative to the real rate of interest are associated with transitory surpluses as revenues tied to income grow faster than spending. As is presently the case in Canada, growth rates are often relied upon to resolve the real impact of deficits arising from countercyclical spending and tax rate inactivity.

Given the long run stationarity of federal deficits and surpluses, it might be thought that there is little room for variations in political competition to influence fiscal stability in Canada. ${ }^{18}$ However, the test for stationarity we report in the first three columns of Table 1 does not carry with it an explanation of how that stability came to be. To begin to investigate the role of changes in political competitiveness and their effect on stability, we re-estimate the ARDL model after adding the electoral competition variables as potential explanatory variables. Doing so reveals that the high degree of correlation arising between PS_Hist_Cons and Adj_AMCons_SD (about 0.6) leads to an underestimate of the significance of the individual contribution of either. We therefore drop Adj_AMCons_SD as an independent indicator of electoral competition. (It will reappear in subsequent models of government size.) The estimation results using the remaining three political competition indicators are presented as columns (4) through (6) in Table $1 .^{19}$

Inspection of the full ARDL equation in column (4) indicates that aside from somewhat more persistence through time, the introduction of the political competition variables has not altered the previous finding of fiscal stability. The value of the Bounds test for cointegration (6.55), found at the bottom of column (5), is again consistent with the existence of a cointegrating relationship arising among the I(1) variables which in turn allows us to interpret the linear relationship described in column (5) as a

\footnotetext{
${ }^{18}$ For a recent general study of the political economy of public debt across countries and time, see Salsman (2017).

${ }^{19}$ While the emphasis in this paper is on electoral competition and its effects on fiscal stability, Ferris, Winer and Grofman (2012) consider the role that institutions play in aligning decision-making incentives and responsibility within the Canadian governance system. Two episodes that alter responsibility for economic policy that first weaken and then strengthen financial stability are examined: the founding of the Bank of Canada in 1935 that led to the division of fiscal responsibility between the Department of Finance (fiscal policy) and the Bank (monetary policy); and the adoption of inflation targeting in 1991 that directed the central bank to focus on inflation control rather than real output or unemployment.
} 
long run equilibrium one. The coefficient estimate on LNTSIZE is now somewhat smaller (0.942) but still insignificantly different from 1, and the FCOST coefficient and regression constant remain insignificantly different from zero. The error correction coefficient and short run adjustment path shown in column (6) again imply convergence back to the equilibrium time path with a speed of adjustment that is unchanged from that estimated earlier. Finally, the ARDL equation passes the CUSUM and CUSUM of squares test for stability with the equation residuals remaining within the $5 \%$ bounds.

A Wald test rejects the hypothesis that the political competition variables as a group add no explanatory power to the equation. Their significant entry in the ARDL model with the indicated signs implies that the data are consistent with variations in the intensity of competition having had a significant, beneficial effect on the degree of fiscal stability over time. ${ }^{20}$ Specifically, the estimated effects of decreases in the proportion of seats held by the governing party, LNSEATS, an indicator of competition between elections, and of increases in the degree of competition at the constituency level in elections, indexed by PS_Hist_Cons, are consistent with the view that greater competition decreased the gap between government spending and taxes over the long run. Note, however, that because these metrics are both stationary and without trend, their significance implies a reduction in the scale of the residual about the prior cointegrating equation. Periods in which the size of the governing majority has been smaller than average and the degree of competition within constituencies has been higher than average are consistently associated with smaller levels of government spending and/or higher levels of taxation. ${ }^{21}$ While the sign of the coefficient estimate on our third political variable, $C V \_$winmargin, is inconsistent with the hypothesis that a wider distribution of winning margins decreases the ability of the government to restrain the spending demands of members of the caucus, the coefficient estimate is insignificantly different from zero.

\section{Political competitiveness and government expenditure and tax size}

A more detailed picture of the role of political competition in helping to establish fiscal stability can be achieved by considering the evolution of expenditure and tax instruments directly. Because they are related through the government budget constraint, we can describe their co-movement through time as a structural simultaneous equation model of the long and short run dimensions of the three fiscal instruments-noninterest government expenditure size relative to GDP, $L N G S I Z E_{t}=\log \left(G_{t} / Y_{t}\right)$, tax size, $\operatorname{LNTSIZE}_{t}=\log \left(T_{t} / Y_{t}\right)$, and a log form proxy for the deficit net of interest payments,

\footnotetext{
${ }^{20} \mathrm{~F}(3,126)=3.43$ with $\mathrm{p}=0.0192$. We also tested for partisan differences with respect to financial stability by including the dummy variable, LIBERAL, for years in which the Liberal Party was in power. The coefficient estimate was insignificant and Its use added no explanatory power to the model.

${ }^{21}$ While PS_Hist_Cons is significantly different from zero at the $5 \%$ significance level, LNSEATS can be considered significant only if the confidence interval is extended to $12 \%$.
} 
$\Delta b_{t}=L N G S I Z E_{t}-\operatorname{LNTSIZE}_{t} \cdot{ }^{22}$ Keeping the form of the autoregressive distributive lag model as general as possible, we assume that at time $t$ the government sector of the economy can be described by the following system of equations:

$$
\begin{aligned}
\operatorname{LNGSIZE}_{t}= & \alpha_{0}+ \\
& +\alpha_{1} \operatorname{LNGSIZE}_{t-1}+\alpha_{2} \operatorname{LNTSIZE}_{t}+\alpha_{3} \operatorname{LNTSIZE}_{t-1}+\alpha_{4} \Delta b_{t}+\alpha_{5} \Delta b_{t-1} \\
& +\alpha_{6} Z_{t}+\alpha_{7} Z_{t-1}+\alpha_{8} X_{t}+\alpha_{9} X_{t-1}+e_{t}^{g} \\
\operatorname{LNTSIZE}_{t}= & \beta_{0}+\beta_{1} \operatorname{LNTSIZE}_{t-1}+\beta_{2} \operatorname{LNGSIZE}_{t}+\beta_{3} L N G S I Z E_{t-1}+\beta_{4} \Delta b_{t}+\beta_{5} \Delta b_{t-1} \\
& +\beta_{6} Z_{t}+\beta_{7} Z_{t-1}+\beta_{8} X_{t}+\beta_{9} X_{t-1}+e_{t}^{t}
\end{aligned}
$$

and

$$
\Delta b_{t} \equiv L N G S I Z E_{t}-L N T S I Z E_{t}
$$

where $Z_{t}$ is a vector of economic fundamentals, $X_{t}$ is the vector of the electoral competition variables introduced and discussed above, and both are treated as co-determinants of $L_{N} G S I Z E_{t}$ and $L_{N T S I Z E_{t}}$. Here $e_{t}^{g}$ and $e_{t}^{t}$ are white noise random variables.

What is immediately obvious is that the three equations cannot be linearly independent even in the short run. By substituting (6) back into the two earlier equations, we can reduce the system to two equations that can be independent (at least in the short run). Doing so results in a two equation system that solves for $L N G S I Z E_{t}$ and $L N T S I Z E_{t}$ simultaneously. However, the presence of each policy variable in the equation of the other means that estimating this form as separate ARDL equations would yield coefficient estimates that are inconsistent and biased. This difficulty is overcome by the successive substitution of one equation into the other to find a reduced form where each fiscal variable becomes a function only of the lagged values of all the political and economic variables and themselves.

The equations for fiscal policy instruments that are estimated below take the general form:

$$
Q_{t}=\alpha_{0}+\sum_{i=1}^{i=n} \alpha_{i} Q_{t-1}+\sum_{j=1}^{j=J} \sum_{i=1}^{i=n} \alpha_{j t} Z_{t}+\sum_{k=1}^{k=J} \sum_{i=1}^{i=n} \alpha_{k t} X_{t}+e_{t}
$$

where $Q=L N G S I Z E$ or $L N T S I Z E, e_{t}$ is a white noise random variable and as a practical matter, $n=4$. In order to separate the role of competitiveness in the long run equilibrium from its contribution to short run adjustment and error correction processes, we again follow Pesaran, Shin and Smith (2001) to estimate

\footnotetext{
22 The log form is appropriate for dealing with modelling errors that arise over the long period we study even though it introduces some awkwardness into the specification of the government budget restraint. We do not need to estimate a system of equations however, as will become clear below.
} 
ARDL models using this structure, This estimation is presented following a discussion of the variables we use to represent the economic fundamentals $X_{t}$ underlying fiscal policy choices.

\subsection{Economic fundamentals as control variables}

Despite the widespread availability of data for Canada, the variables that can be used to proxy economic fundamentals underlying voter demands and economic constraints on policy choices are limited by their need to span the entire one hundred and forty five year period following Confederation. Subject to this restriction, the variables chosen are those often discussed in the growth of government literature and which have been widely used in the study of government expenditure and tax size in democratic states. $^{23}$

The traditional starting point in explaining government size is Wagner's Law, the hypothesis that the size and scope of government increases more than in proportion with society's growth in scale and complexity. This is interpreted as implying that the elasticity of real income per capita (RGDPPC in the tables below) with respect to size is positive. To capture other structural features that may have promoted more (or less) government involvement in the Canadian economy, we use the immigration rate (IMRATIO) and the openness of the economy through the relative size of foreign trade in GDP (OPEN). Immigration has played a major role throughout Canadian history, especially before WWI and in the decade following WWII. The use of OPEN in relation to government size tests Rodrik's (1998) hypothesis that greater openness leads to more government as a form of insurance against external shocks, relative to the competing view that openness restrains government size by imposing more external constraints on feasible levels of taxation (Borcherding et al 2004, Ferris et al 2008). ${ }^{24}$

Urbanization is a structural feature suggested by Kau and Rubin (1981) as a constraint on the ability of the government to tax effectively. Because urbanization is unavailable for our entire time period, we utilize its inverse - the percentage of the population in agriculture $(A G R / C)$ and hence predict a negative relationship of this variable with size. Many studies of the long run size of government also find that the age structure of the population matters and use for this purpose the proportion of the population that is sixty-five or older (e.g., Cukierman and Meltzer, 1989; Ferris and West, 1996). For Canada, from 1870 onward, we have available only the proportion of the population that is less than 16 years old or younger (YOUNG). This we expect to exert upward pressure on government size through increased demand for

${ }^{23}$ For a more detail see Winer and Ferris (2008). Other papers using similar variables include: Borcherding (1985); Mueller (1986); Payne and Ewing (1996); and Borcherding et al (2004).

24 Population size is often included to test for economies of scale. As is common with much of the literature, we find no evidence of economies of scale in the provision of government services. 
government provided health and public schooling. ${ }^{25}$ Finally, another look at Figure 1 indicates clearly that the two world wars have had a dramatic effect on government spending. Hence dummy variables for outliers associated with the Great Depression and war years are added.

With the exception of the war year dummies, all of the economic variables are used in log form, indicated as such in the tables by the addition of the prefix $L N$ to the variable names. ${ }^{26}$ The descriptive statistics for these variables are presented in the Appendix where, to recall, it is noted that together with LNGSIZE and LNTSIZE, the explanatory variables used in the long run model of government size are typically nonstationary in levels and stationary in first differences.

\subsection{Political competition and long run government size}

The best fitting versions (according to the Schwarz criterion) of the ARDL models of expenditure size are presented in columns (1) through (4) of Table 2, while columns (5) through (8) present the corresponding versions for Canada's tax size. All equations work well, explaining over ninety eight percent of these variations in government size. In each set of size groupings, the equations in the first two columns use only economic and demographic fundamentals as determinants of size while the second set of two add the electoral competition variables to the fundamental controls. In all cases the Bounds test statistic (shown at the bottom of each long run column) is consistent with the existence of a cointegrating relationship arising among the I(1) covariates. The long run cointegrating equations implied by each ARDL model are then presented in the odd numbered columns, (1) through (7), followed by their corresponding short run adjustment and error correction processes in the even columns (2) through (8). The error correction coefficients - shaded and found at the bottom of each short run model - are all significantly negative, implying that departures converge back onto the estimated equilibrium time path. Hence both shock and covariate changes that produce short run deviations from the equilibrium time path are transitory, reacted to in a way that brings government size back to its long run equilibrium. Both models are similar in pointing to specific war years as time periods of extraordinary change in expenditures and taxes change. ${ }^{27}$ Accounting for the specificity of these short run effects results in a stable ARDL model where the equation residuals all remain within the bounds of the standard CUSUM and CUSUM squared tests. ${ }^{28}$ (To economize on space these graphs are not presented but are available upon request.)

\footnotetext{
${ }^{25}$ Although health and education are a provincial responsibility in Canada, the federal government provides considerable funding for these services though intergovernmental transfers.

${ }^{26}$ GSIZE, TSIZE, IMRATIO, AGRIC, YOUNG, OPEN and SEATS are all fractions constrained to lie between zero and one. Transforming these variables into percentages and logarithms avoids restrictions on the domain of the error terms.

${ }^{27}$ Note that 1920 was the year leading into the $14^{\text {th }}$ election in 1921, the first federal election in which all women could vote; 1940 was the first full year of WW2 Canada; and 1942 (1946) was the mid (end)-point in Canada's WW2 participation.

${ }^{28}$ Note also that accounting for the influence of political variables increases the long run effect of LNRGDPPC.
} 
Table 2: ARDL Models of the Expenditure and Tax Size of Government, Canada 1870 - 2015 (Newey West standard errors in brackets; lags selected using the Schwarz criterion)

\begin{tabular}{|c|c|c|c|c|c|c|c|c|}
\hline $\begin{array}{c}\text { Equation Type } \\
\text { Dependent Variable }\end{array}$ & $\begin{array}{c}\text { (1) } \\
\text { LONG RUN } \\
\text { LNGSIZE }\end{array}$ & $\begin{array}{c}\text { (2) } \\
\text { SHORT RUN } \\
\text { D(LNGSIZE }\end{array}$ & $\begin{array}{c}\text { (3) } \\
\text { LONG RUN } \\
\text { Political } \\
\text { LNGSIZE }\end{array}$ & $\begin{array}{c}\text { (4) } \\
\text { SHORT RUNZ } \\
\text { Political } \\
\text { D(LNGSIZE) }\end{array}$ & $\begin{array}{c}\text { (5) } \\
\text { LONG RUN } \\
\text { LNTSIZE }\end{array}$ & $\begin{array}{c}\text { (6) } \\
\text { SHORT RUN } \\
\text { D(LNTSIZE) }\end{array}$ & $\begin{array}{c}\text { (7) } \\
\text { LONG RUN } \\
\text { Political } \\
\text { LNTSIZE }\end{array}$ & $\begin{array}{c}\text { (8) } \\
\text { SHORT RUN } 2 \\
\text { Political } \\
\text { D(LNTSIZE) }\end{array}$ \\
\hline D(LNGSIZE(-1)) & & $\begin{array}{c}0.393^{* * *} \\
(0.050)\end{array}$ & & $\begin{array}{c}0.366^{* * *} \\
(0.047)\end{array}$ & & & & \\
\hline D(LNTSIZE(-1)) & & & & & & $\begin{array}{l}0.386 * * * \\
(0.062)\end{array}$ & & $\begin{array}{c}0.435 * * * \\
(0.060)\end{array}$ \\
\hline D(LNTSIZE $(-2))$ & & & & & & $\begin{array}{c}-0.328^{* * *} \\
(0.063)\end{array}$ & & $\begin{array}{c}-0.280^{* * *} \\
(0.058)\end{array}$ \\
\hline LNAGRIC & $\begin{array}{l}-0.061 \\
(0.242)\end{array}$ & & $\begin{array}{l}-0.126 \\
(0.182)\end{array}$ & & $\begin{array}{l}-0.022 \\
(0.137)\end{array}$ & & $\begin{array}{l}-0.018 \\
(0.083)\end{array}$ & \\
\hline LNYOUNG & $\begin{array}{c}1.829 * * * \\
(0.340)\end{array}$ & & $\begin{array}{c}1.935^{* * *} \\
(0.348)\end{array}$ & & $\begin{array}{c}1.700^{* * *} \\
(0.366)\end{array}$ & & $\begin{array}{c}1.510^{* * *} \\
(0.204)\end{array}$ & \\
\hline LNOPEN & $\begin{array}{l}0.088 \\
(0.374)\end{array}$ & & $\begin{array}{l}0.158 \\
(0.293)\end{array}$ & & $\begin{array}{l}0.367^{*} \\
(0.221)\end{array}$ & & $\begin{array}{l}0.069 \\
(0.121)\end{array}$ & \\
\hline LNIMRATIO & $\begin{array}{l}-0.069 \\
(0.056)\end{array}$ & & $\begin{array}{c}-0.074^{* *} \\
(0.037)\end{array}$ & & $\begin{array}{c}-0.149 * * * \\
(0.043)\end{array}$ & & $\begin{array}{c}-0.151^{* * *} \\
(0.023)\end{array}$ & \\
\hline D(LNIMRATIO) & & $\begin{array}{c}-0.085^{* * *} \\
(0.021)\end{array}$ & & & & & & $\begin{array}{l}-0.001 \\
(0.010)\end{array}$ \\
\hline D(LNIMRATIO(-1)) & & & & & & & & $\begin{array}{c}0.044^{* * *} \\
(0.010)\end{array}$ \\
\hline D(LNIMRATIO(-2)) & & & & & & & & $\begin{array}{c}-0.327^{* * *} \\
(0.063)\end{array}$ \\
\hline LNRGDPPC & $\begin{array}{c}0.816^{* * *} \\
(0.293)\end{array}$ & & $\begin{array}{c}0.912^{* * *} \\
(0.217)\end{array}$ & & $\begin{array}{c}0.733^{* * *} \\
(0.170)\end{array}$ & & $\begin{array}{c}0.822^{* * *} \\
(0.114)\end{array}$ & \\
\hline $\mathrm{D}($ LNRGDPPC) & & $\begin{array}{c}-0.708^{* * *} \\
(0.144)\end{array}$ & & $\begin{array}{c}-0.688^{* * *} \\
(0.126)\end{array}$ & & $\begin{array}{c}-0.332^{* * *} \\
(0.073)\end{array}$ & & $\begin{array}{c}-0.327^{* * *} \\
(0.064)\end{array}$ \\
\hline $\mathrm{D}($ LNRGDPPC $(-1))$ & & $\begin{array}{c}0.533^{* * *} \\
(0.166)\end{array}$ & & & & $\begin{array}{l}0.154^{*} \\
(0.078)\end{array}$ & & $\begin{array}{l}-0.033 \\
(0.081)\end{array}$ \\
\hline D(LNRGDPPC(-2)) & & & & & & $\begin{array}{c}-0.280^{* * *} \\
(0.076)\end{array}$ & & $\begin{array}{c}-0.330^{* * *} \\
(0.080)\end{array}$ \\
\hline $\mathrm{D}($ LNRGDPPC(-3) & & & & & & & & $\begin{array}{c}-0.179^{* *} \\
(0.073)\end{array}$ \\
\hline LNSEATS & & & $\begin{array}{l}0.659 * * \\
(0.271)\end{array}$ & & & & $\begin{array}{c}0.592^{* * *} \\
(0.124)\end{array}$ & \\
\hline CV_winmargin & & & $\begin{array}{l}-0.025 \\
(0.024) \\
\end{array}$ & & & & $\begin{array}{l}-0.012 \\
(0.012)\end{array}$ & \\
\hline $\mathrm{D}(\mathrm{CV}$ _winmargin) & & & & & & & & $\begin{array}{c}-0.008^{* *} \\
(0.004)\end{array}$ \\
\hline$D\left(C V \_\right.$winmargin(-1)) & & & & & & & & $\begin{array}{l}0.012^{* *} \\
(0.004)\end{array}$ \\
\hline PS_Hist_Cons & & & $\begin{array}{l}-0.105 \\
(0.367)\end{array}$ & & & & $\begin{array}{c}0.649 * * * \\
(0.189)\end{array}$ & \\
\hline Adj_AMCons_SD & & & $\begin{array}{l}-0.215 \\
(0.227)\end{array}$ & & & & $\begin{array}{l}-0.237^{*} \\
(0.139)\end{array}$ & \\
\hline D(Adj_AMCons_SD) & & & & & & & & $\begin{array}{c}-0.141^{* * *} \\
(0.033)\end{array}$ \\
\hline LIBERAL & & & $\begin{array}{l}-0.146^{*} \\
(0.080)\end{array}$ & & & & $\begin{array}{l}-0.026 \\
(0.037)\end{array}$ & \\
\hline CONSTANT & & $\begin{array}{l}-2.045 \\
(4.584)\end{array}$ & $\begin{array}{c}-15.46^{* * *} \\
(3.21)\end{array}$ & & $\begin{array}{c}-11.40^{* * *} \\
(2.705)\end{array}$ & & $\begin{array}{c}-12.98^{* * *} \\
(1.52))\end{array}$ & \\
\hline $\begin{array}{l}\text { Error correction term }{ }^{2} \\
(1 \% \mathrm{CV}=4.79)\end{array}$ & & $\begin{array}{c}-0.177^{* * *} \\
(6.78)\end{array}$ & & $\begin{array}{c}-0.259^{* * *} \\
(11.43)\end{array}$ & & $\begin{array}{c}-0.108^{* * *} \\
(6.98)\end{array}$ & & $\begin{array}{c}-0.183^{* * *} \\
(9.57)\end{array}$ \\
\hline $\begin{array}{r}\text { Bounds Test } \\
\text { Critical upper bound }\end{array}$ & $\begin{array}{l}7.372 \\
5.163\end{array}$ & & $\begin{array}{c}9.983 \\
3.68\end{array}$ & & $\begin{array}{l}6.637 \\
4.587\end{array}$ & & $\begin{array}{l}6.95 \\
3.68\end{array}$ & \\
\hline $\begin{array}{r}\text { Observations } \\
\text { Adj_R }\end{array}$ & $\begin{array}{c}142 \\
0.982\end{array}$ & & $\begin{array}{c}140 \\
0.983\end{array}$ & & $\begin{array}{c}142 \\
0.993\end{array}$ & & $\begin{array}{c}140 \\
0.995\end{array}$ & \\
\hline
\end{tabular}

Notes: ${ }^{*}(* *)\left[{ }^{* *}\right]$ significantly different from zero at $10 \%(5 \%)[1 \%] .{ }^{\mathrm{t}}$ The recursive residuals pass the CUSUM and CUSUM of Squares tests at $5 \%$. ${ }^{2}$ Error correction term presents absolute value of t-statistic to allow easier comparison with critical $1 \%$ value. The equations include dummy variables for WW1, 1930, 1940,1942 and 1946 (discrete changes in spending with the Depression and about world wars). 
For both long run models of government size, the relationships found between the different variables used to proxy economic fundamentals and size conform to expectation. The trending reduction in agriculture's share of production (corresponding to an increase in urbanization and industrialism) is associated with a larger government size, but only weakly so. On the other hand, increases in the share of the population that is young and increases in real GDP per capita, are both associated significantly with increases in both the expenditure and tax measure of government size. Hence the evidence is strongly consistent with Wagner's Law holding for Canada, while periods of baby boom (and busts) are met with greater (less) than proportional expansions in both spending and taxes. Periods with larger immigration flows have a similarly signed negative effect on both expenditure and tax sizes of government but are found to be significant only on the tax side. Finally, the data is not inconsistent with Rodrik's (1998) hypothesis that greater trading openness promotes a larger sized government, but weakly so, with the effect significant only for the tax size of government, and then only at $10 \%$.

The addition of the four political competition variables improves the fit of the equations and generates results that are consistent with the view that political competition enhances fiscal stability and reduces political rents. Unlike in the fiscal stability investigation in Table 1 however, the models in Table 2 indicate the presence of a partisan effect reflected by the significance of the dummy variable for a $L I B E R A L$ government. The results are shown in columns (3-4) for expenditure size, and in (7-8) for tax size. A Wald test of the hypothesis that the four political competition variables and LIBERAL have no effect on LNGSIZE can be rejected, with the probability ( $p$-value) that the political variables having no effect equal to 0.03 . A similar Wald test on LNTSIZE finds the probability that the political competition variables have no effect is even smaller at 0.0001.

Of the four different measures of electoral competitiveness, the metric that has the most significant long run effect on both measures of size is LNSEATS (an elasticity of 0.659 for its effect on expenditure and 0.592 for taxation). That is, the data indicates that the larger is the seat majority held by the winning political party in the House, independently of party ideology, the larger are both measures of government size. This is consistent with the hypothesis that parties with larger governing majorities face less effective opposition in the legislature and hence have greater opportunity to realize political rents through larger government size. The results also suggest that the expansion in expenditure size is financed not just by raising the level of current taxation, but also by spreading tax increases over later generations through increased deficits. There is some suggestion that a wider distribution of governing party winning margins has a constraining effect on government's expenditure or tax size. However, to the extent that a wider distribution of constituency winning margins indicates less party unity and more difficulty 
maintaining individual member interest in 'public' versus 'private' interests, the estimated long run effect is weak and insignificantly different from zero.

While greater competition in the House - that is, a smaller government seat share - is strongly associated with constraining political rent seeking by restraining both measures of government size, the effect of greater electoral competition among candidates within each constituency (PS_Hist_Cons) is somewhat different. Greater electoral competition within constituencies is weakly associated with smaller government expenditures (-0.105), but significantly associated with higher taxes (0.649). To the extent that greater intra-riding competition increases the candidate's reliance on the national party, the party appears better able to enhance fiscal stability by raising taxes than by countering constituency centered rent-seeking by restraining overall spending.

The data also suggest that increases in the degree of contestability in the federal election, indexed here by the asymmetry adjusted measure of marginal seats Adj_AMCons_SD, reduces both the expenditure and tax sizes of Canada's federal government. However, while the estimated effect on the revenue size of government $(-0.237)$ is significant, the estimated effect on expenditure is not. Because the two coefficient estimates are insignificantly different in size, the data suggests any increase in the number and/or symmetry of marginal seats in a federal election that make the election more contestable would reduce long run government size without consequences for the public debt.

Finally, a partisan effect on government size again shows up in the table. Perhaps surprising for what is now commonly thought of as a left of center party, periods of Liberal Party governing tenure are associated with smaller, rather than larger, expenditure and revenue sizes. This effect is significant, but only at the $10 \%$ level.

\subsection{Short run variation in government size}

One advantage of ARDL modeling is that by separating the long run from the short run relationships arising in the data, the estimation indicates which variables have power in the long versus the shorter run and allows the same relationship to indicate a different role in the short run as opposed to the long run. One example of the latter that stands out in our results is the relationship arising between the two measures of government size (LNGSIZE and LNTSIZE) and real income per capita (LNRGDPPC). For example, in columns (1) and (3) of Table 2, the data indicate that there is a strong positive (Wagner's Law type) long run relationship arising between both size measures and real income per capita. However, in columns (2) and (4) the data indicate that in the short run, government expenditure size varies inversely with real income per capita and with dramatically large elasticity values. Rather than being consistent with the long relationship implied by Wagner's Law or government size being complementary to private output, the 
short run relationship indicates that government spending plays a countercyclical role in relation to the business cycle. As the growth of real per capita income falls (rises) government spending clearly increases (decreases) concurrently, with that increase (decrease) beginning to reverse itself as early as the following year. Government tax size, on the other hand, tends to be somewhat procyclical, increasing rather than falling relative to income. Overall, however, the net effect of short run fiscal policy is evidently stimulative rather than contractionary, with transitory countercyclical changes in spending dominating smaller changes in taxes.

A second feature of interest is that $C V_{-}$winmargin is the one political variable that is more significant in the short run adjustment process than the long run. The result here is consistent with the hypothesis that a wider distribution of volatility adjusted winning margins across constituencies won by the governing party creates a temporary disruption to rent seeking by the governing party, but that this is transitory in nature. Of the economic variables, only immigration flows are found to exhibit significant short run effects. Like the case of $L N R G D P P C$, the sign of the short run effect is opposite to that found in the long run, exerting an immediate expansionary effect on tax size that is reversed over time.

Finally, while we have seen that the negative signs on the error correction term in all four sets of equations are consistent with convergence back to the cointegrating equation, it is important to note that in all cases, the absolute size of the error correction coefficient is increased when political competition variables are introduced. In the case of expenditure size, the error correction coefficient falls in size from -0.177 to -0.259 , where the 0.122 difference is more than five times the standard error of 0.026 . The result for convergence on the tax side is similar. The error correction coefficient falls in size from -0.108 to 0.183 , with the 0.075 difference more than four times larger than the 0.015 standard error.

In summary, the introduction of our electoral competition variables into these ARDL models generates results that are consistent with increases in electoral competition: reducing the scale of political rents embodied in the expenditure and tax sizes of government; improving convergence by increasing the rate at which short run departures return to the long run equilibrium path set by fundamentals; and increasing financial stability by bringing closer together government spending and revenue plans and stabilizing government debt. It should also be noted that while most of our measures of political competition work in some way to support these hypotheses, each measure plays a different role or has a different effect with respect to time. ${ }^{29}$ Some metrics, for example, exhibit a significant effect on only one dimension of policy; Adj_AMCons_SD has a significant influence only the tax size of government while CV_winmargin appears significant in the short run alone. The significant appearance of LNSEATS in all

\footnotetext{
${ }^{29}$ The exception is CV_winmargin. While not often significant it consistently appears with an estimated sign opposite to that expected from the perspective of Aldrich and Rohde (2000).
} 
models is supportive of a modified version of the hypothesis recently advanced by Cox and Weingast (2017), that 'the health of the legislature' is at least as important as 'the health of the election'. Here the moderating phrase 'at least as' comes from the significant influence of both asymmetrically adjusted marginal constituencies and of competition among candidates at the constituency level on the tax size of government.

\section{Does electoral competition matter for countercyclical fiscal policy?}

Before turning to the quantitative effect of competition, in this section we look explicitly at how fiscal policy, as measured by the size of the federal government's operating deficit, responds to the business cycle and at the extent to which electoral competition has influenced the scale of that response. ${ }^{30}$ The influence of electoral competition on fiscal policy is measured by interacting the competition variables with our measure of the business cycle, the growth rate of real income per capita, $D(L N R G D P P C)$, denoted GROWTH_RATE in the tables of results.

Because the fiscal deficit and the growth rate are both stationary, ARDL modeling is not necessary and the relationship between the deficit and growth can be estimated by OLS. ${ }^{31}$ To the extent that the deficit can also reflect changes arising from the adjustment process to changes in long run government size, we include the first differences of the previous control variables and FCOST (which are both stationary) as alternative explanations of the deficit's size. In the following table we present two models: column (1) shows how the deficit responds to changes in the model's fundamentals, while column (2) incorporates the interacted electoral competition variables.

[Table 3 here]

\footnotetext{
${ }^{30}$ We recall that LNDEFICIT $\equiv$ LNGSIZE - LNTSIZE where government spending does not include interest payments.

${ }^{31}$ The growth rate of real GDP per capita is stationary about a growth rate of 2 percent over our time period.
} 
Table 3

The Effect of Electoral Competition on Countercyclical Fiscal Response, Canada 1879 - 2015

(Newey West standard errors in brackets; lags selected using the Schwarz criterion)

\begin{tabular}{|c|c|c|}
\hline Dependent Variable & $\begin{array}{c}(1) \\
\text { LNDEFICIT }\end{array}$ & $\begin{array}{c}(2) \\
\text { LNDEFICIT }\end{array}$ \\
\hline LNDEFICIT(-1) & $\begin{array}{c}1.244^{* * *} \\
(0.055)\end{array}$ & $\begin{array}{c}1.254^{* * *} \\
(0.058)\end{array}$ \\
\hline LNDEFICIT(-2) & $\begin{array}{c}-0.420 * * * \\
(0.053)\end{array}$ & $\begin{array}{c}-0.438^{* * *} \\
(0.053)\end{array}$ \\
\hline D(LNAGRIC) & $\begin{array}{l}-0.067 \\
(0.197)\end{array}$ & $\begin{array}{l}-0.019 \\
(0.191)\end{array}$ \\
\hline D(LNYOUNG) & $\begin{array}{l}-0.625 \\
(0.757)\end{array}$ & $\begin{array}{l}-0.600 \\
(0.747)\end{array}$ \\
\hline D(LNIMRATIO) & $\begin{array}{l}-0.030 \\
(0.024)\end{array}$ & $\begin{array}{l}-0.019 \\
(0.024)\end{array}$ \\
\hline $\mathrm{D}($ LNOPEN) & $\begin{array}{c}-0.300 * * \\
(0.119)\end{array}$ & $\begin{array}{c}-0.405^{* * *} \\
(0.120)\end{array}$ \\
\hline FCOST & $\begin{array}{c}0.001 \\
(0.002)\end{array}$ & $\begin{array}{c}0.001 \\
(0.002)\end{array}$ \\
\hline GROWTH_RATE & $\begin{array}{c}-0.709 * * * \\
(0.225)\end{array}$ & $\begin{array}{l}-2.268 \\
(4.280)\end{array}$ \\
\hline GROWTH_RATE(-1) & $\begin{array}{l}0.303^{*} \\
(0.187)\end{array}$ & $\begin{array}{c}0.218 \\
(0.161)\end{array}$ \\
\hline GROWTH_RATE*LNSEATS & & $\begin{array}{c}1.054 \\
(1.058)\end{array}$ \\
\hline GROWTH_RATE*D(CV_winmargin) & & $\begin{array}{c}-0.568 * * * \\
(0.203)\end{array}$ \\
\hline GROWTH_RATE*PS_HIST_CONS & & $\begin{array}{c}-3.200 * * \\
(1.393)\end{array}$ \\
\hline GROWTH_RATE*ADJ_AMCONS_SD & & $\begin{array}{l}-0.752 \\
(0.603)\end{array}$ \\
\hline CONSTANT & $\begin{array}{l}-0.016 \\
(0.011)\end{array}$ & $\begin{array}{l}-0.007 \\
(0.011) \\
\end{array}$ \\
\hline $\begin{array}{r}\text { Observations } \\
\text { Adj } R^{2}\end{array}$ & $\begin{array}{l}140 \\
.912\end{array}$ & $\begin{array}{l}141 \\
.921\end{array}$ \\
\hline Wald $[c(8)=c(9)=c(10)=c(11)=0]$ & & $\begin{array}{c}F(4,122)=4.23 \\
\text { Prob }=.003\end{array}$ \\
\hline
\end{tabular}

Notes: ${ }^{*}\left({ }^{* *}\right)[* * *]$ significantly different from zero at $10 \%(5 \%)[1 \%]$.The equations include dummy variables for WW1, 1930 and 19401942 and 1946 (discrete changes in spending with the Depression and about the world war years.) 
As the OLS regression results in column (1) make apparent, the deficit varies inversely with the growth rate, consistent with the earlier observation that non-interest government spending less taxes responds countercyclically to the business cycle. While the contemporaneous countercyclical response in the deficit begins to be offset as early as the following year, the persistence of deficits, as indicated in the equation's dynamics, means that any initial shock to deficit size will initiate a prolonged countercyclical change that returns only slowly to its pre-shock level. ${ }^{32}$ It is also of interest to note that from the set of variables used as fundamental determinants of government size, only changes in the degree of openness have a significant (negative) effect on the size of the deficit.

The addition of the interacted electoral competition variables in column (2) does add significant explanatory power to the model--a Wald test reveals that the probability that the set of variables add no explanatory is only 0.003. In addition, the presence of these variables has brought about a significant reduction in the absolute size and significance of the estimates of the deficit's response to the cycle while leaving the other coefficient estimates in column (1) largely unchanged. The combination of adding significant explanatory power to the model and finding reduced significance to the measure of direct deficit response to the cycle suggests that electoral competition has been at least in part responsible for the scale of countercyclical intervention. More particularly, the data indicates that increases in the degree of competition within electoral constituencies (PS_Hist_Cons) and the distribution of winning margins among the winning party ( $C V \_$winmargin) are associated with a significant increase in the deficit's response to the cycle. ${ }^{33}$ The signs of the coefficient estimates on the size of the governing party's majority (LNSEATS) and the proportion and/or symmetry of electorally marginal constituencies (Adj_AMCons_SD) are also consistent with greater countercyclical intervention, but are individually insignificantly different from zero. Here the aggregate of the electoral competition variables is more significant and meaningful than its individual parts. ${ }^{34}$

\section{Does the intensity of electoral competition matter? The debt crisis of the late 1980s}

While the analysis so far supports the hypothesis that electoral competition has made a significant statistical impact in consolidating Canada's fiscal structure, one can still ask whether statistical significance

\footnotetext{
${ }^{32}$ Causality is likely to run both ways in the relationship between government size and per capita output implying that the interpretation of the significant correlation found needs to be read with caution. However, because the effect of size on output is likely positive, there is reason to believe that the size of the countercyclical response suggested above is understated rather than overstated. See Ferris and Voia (2017).

${ }^{33}$ Note that $C V$ _winmargin's coefficient estimate is significant but again opposite in sign to that expected from the Aldrich and Rohde hypothesis. The data is more consistent with the hypothesis that the governing party is more responsive to the community the larger is the proportion of its constituencies in fear of losing re-election.

${ }^{34}$ As with the fiscal stability analysis in Table 1 , the partisan dummy LIBERAL adds no explanatory power.
} 
translates into the potential for making an economically meaningful contribution to Canada's fiscal performance? To address this question we consider the role that electoral competition has played in relation to the federal debt crisis that arose in Canada throughout the 1980s into the early 1990s. Was electoral competition lacking in some sense during this period of apparent fiscal instability and, if so, would an increase in electoral competition have made an important difference to this fiscal history?

In Figure 4 we plot, as the solid upper line, the log deficit size (as a proportion of GDP) of the federal government's budget between the years 1975 and 1994. Over that time period, multiple years of high fiscal deficits, in combination with loose monetary policy, resulted in high rates of inflation and ultra high interest rates (hitting $21 \%$ in August 1982). This in turn produced a vicious circle of federal borrowing, as high servicing costs required even higher levels of federal borrowing simply to maintain existing deficit levels. Together these factors produced a rapid growth in the outstanding stock of federal government debt, rising from 20 percent of GDP in 1971 to almost 60 percent by the mid 1990s. While operating surpluses did begin earlier, it was only following the election of the Liberal government under Jean Chretien in 1993 that an all-party consensus developed to tackle the federal debt issue, allowing for a dramatic cut back in government expenditures of all kinds and the generation of successive operating budget surpluses.

Figure 4

LNDEFICIT actual and adjusted for a $10 \%$ increase in electoral competition

Canada: 1975 - 1993

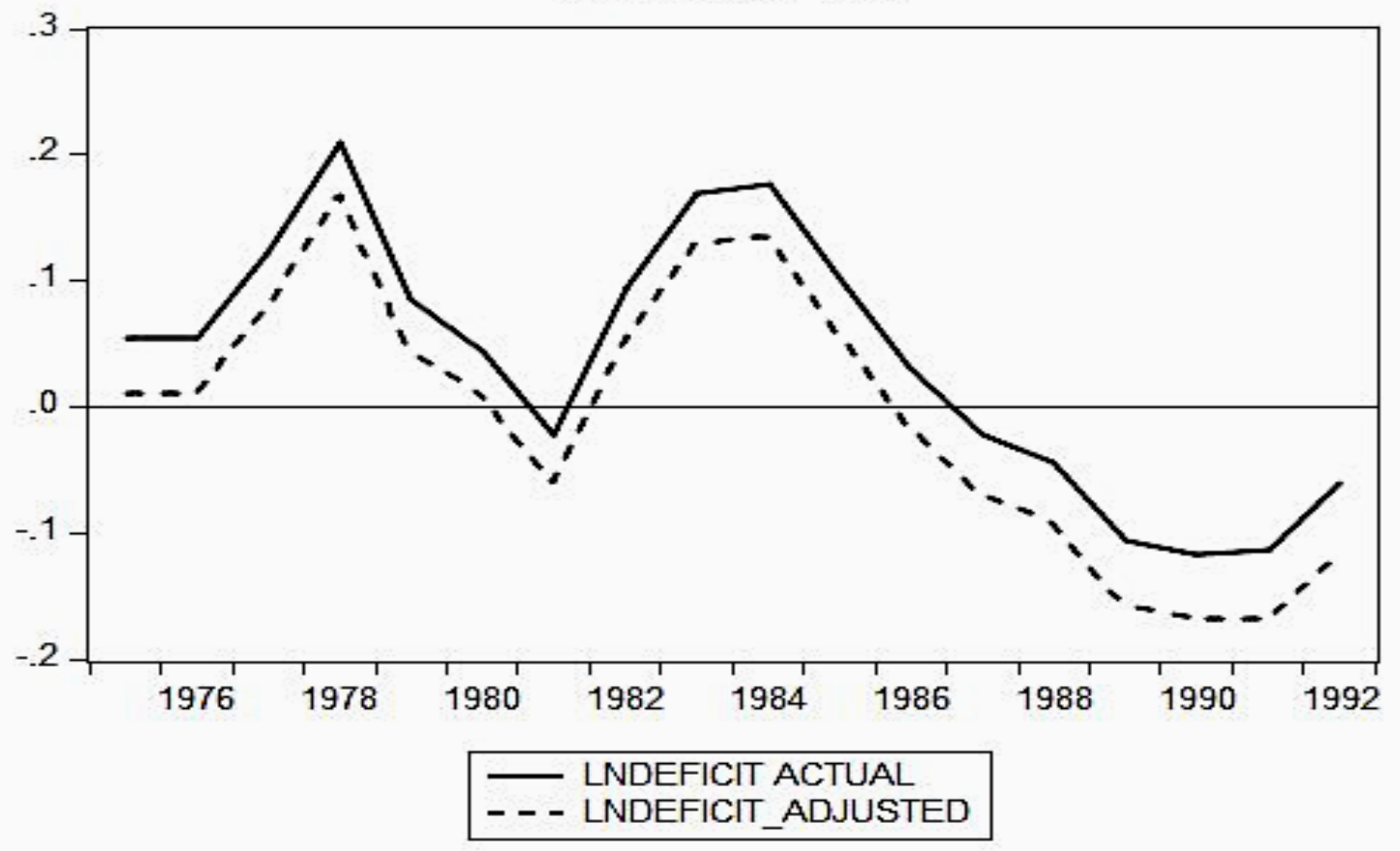


From the perspective of this paper, we can ask what was happening to electoral competition over this period by examining the actual level of our electoral competition measures relative to their longer term means. In Figure 5 the levels and movement of three of these variables relative to their means is shown. As that diagram suggests, the two election variables - PS_Hist_Cons and Adj_AMS_SD (scaled on the left axis) - were well below their overall mean for large parts of this period, while the third variable, LNSEATS (scaled on the right axis), began the period just below its mean before rising well above for the latter half of the 1980s. The similar time patterns exhibited by the two election measures imply that the degree of competition within election constituencies and among the competing national parties was well below normal from as early as 1976.

Figure 5

Electoral Competition Variables and Means

Canada: 1975 - 1995

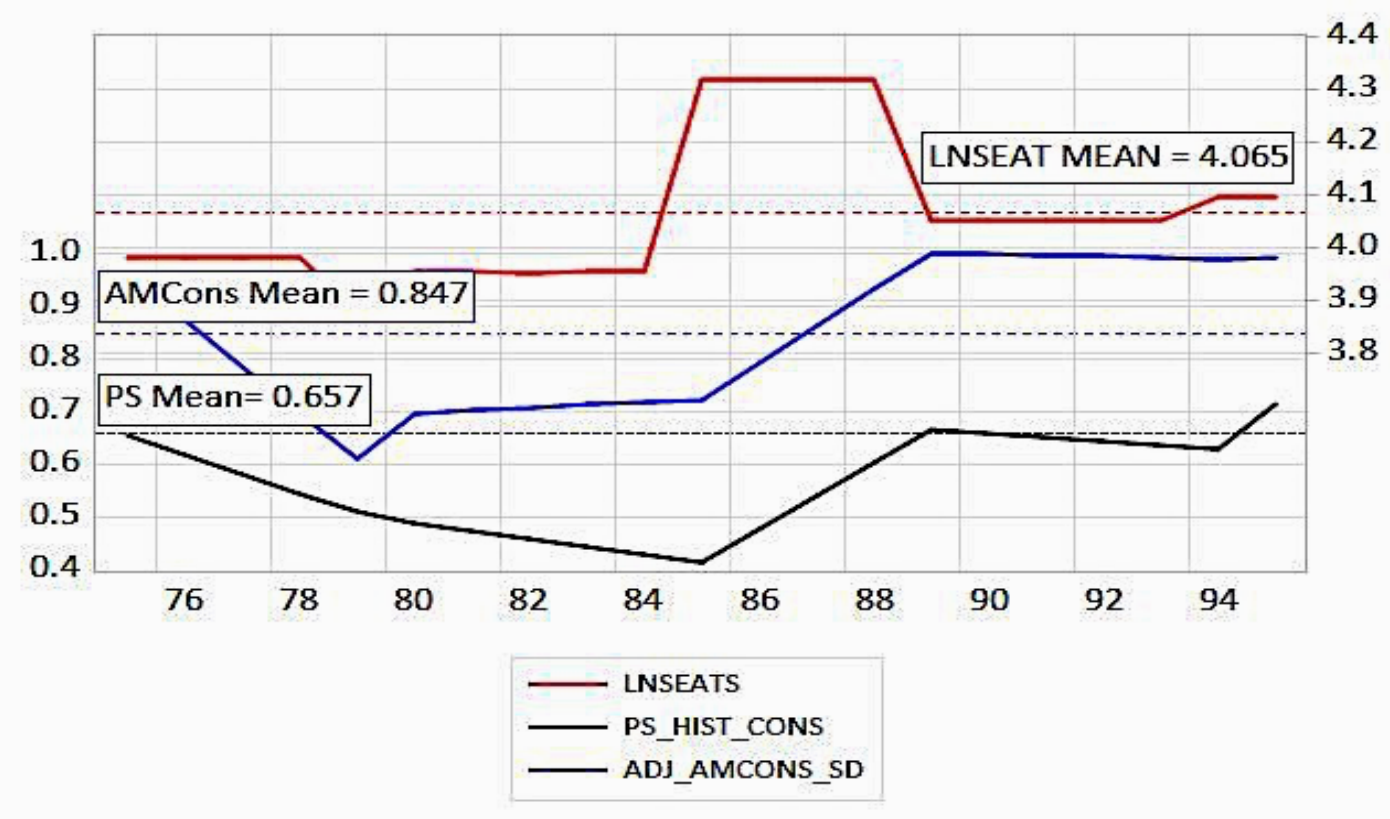

The level of competition intensity remained below average through the mid 1980s before slowly rising back to the long run in the late 1980s. The seat majority held by the governing party, on the other hand, entered the period slightly below its mean but, following the Mulroney election of 1984, rose well above for the remainder of the 1980s before falling back to the mean by the early 1990s. This indication of a reduction in competition within the legislature arose at a time to counter the low but slowly rising level of political competition in the elections. Thus while the two sets of measures differed in the specific time intervals for which they indicate a lack of competition, in combination they imply that overall the level 
of competition was less than usual throughout. Political competition returned to normal for all our metrics only as the debt crisis was peaking.

To measure the potential importance of electoral competition, we can ask what would have been the effect of an increase in the degree of political competition as measured by our model. Would greater political competition have helped to reduce the federal deficit in the 1980s and 1990s? To implement this counterfactual, we use the long run coefficient estimates from Table 3, and raise the Przeworski-Sprague multi-party constituency level index, and the asymmetrically adjusted marginal seat by party, by 2 percent each, while reducing the size of the seat majority held by the governing party and the coefficient of variation of its winning margins by the same 2 percent. This generates a prediction of what long run deficits would have arisen had these dimensions of political competition been quite modestly improved, all other factors remained unchanged. The newly predicted pattern of the log differences in deficits that this two percent improvement in long run competitiveness would have made to LNDEFICITSIZE is shown as the dashed line on Figure 2.

The story told by this counterfactual is striking. While the time pattern of deficits rising and falling over that period would not have changed, the marginal increase in average competitiveness would have shifted the time path of deficits downwards. As such the model suggests that greater competitiveness would not only have had an important effect on the size of annual federal deficits, but also altered favourably the growth rate of federal debt. With greater competition federal government debt would have risen much more slowly, peaked at a much lower level, and began its decline from peak size much earlier. How the intensity of political competition in Canada could have, and can now be increased is another matter, and is a subject for further research and debate.

\section{Conclusion}

In this paper we ask, to our knowledge for the first time, whether political competition in and between elections has played a significant role in explaining variations in important aspects of the Government of Canada's fiscal structure: its financial stability, its expenditure and tax size, and the scale of its countercyclical intervention. The short answer is that electoral competition as we have measured it does

play a significant role in relation to all fiscal dimensions. ARDL modelling using data covering the history of the modern state reveals correlations that are consistent with the hypotheses that greater electoral competition enhances fiscal stability, speeds up the convergence of government size from above on fundamentals, and help align fiscal deficits better with the business cycle.

The empirical results are also interesting in their detail, suggesting that electoral competition may influence some policies more than others and that the different dimensions of competition may work to 
influence some aspects of fiscal policy better than others, often in different ways. ${ }^{35}$ For example, the data are consistent with the effects of electoral competition being strongest with respect to government size. A fall in political competition as measured by an increase in the size of the seat majority held by the governing party is associated with a significant increase in both the expenditure and tax sizes of government. Here the increase in expenditure exceeds that of taxes resulting in a net increase in the deficit. A similar reduction in the degree of competition within Canada's federal election ridings is associated with an unambiguous increase in deficit size, the significant increase in spending magnified by a significant reduction in taxes. On the other hand, an increase in the proportion and/or symmetry of marginal constituencies is associated with a significant reduction in tax size alone while an increase in the dispersion of volatility adjusted winning margins produces only a transitory effect, decreasing tax size. While the data are consistent with greater electoral competition bringing long run government size closer to that desired by the electorate, the data also suggest that a more competitive political environment increases the speed at which departures from long run government size converge back onto the time path dictated by underlying fundamentals.

Finally, with respect to the business cycle, the data we have assembled show that while fiscal deficits have always been strongly counter-cyclical, the effect produced by greater electoral competition is consistent with generating greater fiscal deficit response. In this case it is greater intra-constituency competition and a widening of the distribution of winning margins across constituencies won by the governing party that appear to be most responsible.

The paper concludes by applying the model to the period of federal debt instability arising throughout the 1980s and into the 1990s. This exercise indicates that political competition as measured by our variables was below average throughout the buildup of federal debt and points to how even a small increase in its intensity could have played an important role in minimizing the risk of fiscal instability. The counterfactual points to the importance of electoral engineering as a way to achieve greater fiscal responsibility, provided that the competitiveness of the electoral system is explicitly considered a target of reform. Whether the debates and developments in this respect that have been arising periodically over the past decade at the federal and provincial levels in Canada are moving the country in this, more competitive, direction remains to be studied.

\footnotetext{
${ }^{35}$ Of the four different dimensions of control (or lack thereof) over agency externalities, only the hypothesis that the cohesiveness of the governing political party, as measured by the coefficient of variation of its winning margins, is an effective control over constituency externalities is rejected by the data.
} 


\section{Data Appendix}

The data for this study were collected over a long period of time from a wide variety of sources. The economic data together with a complete definition, description and sourcing of each variable will be made available at the web site http://www.carleton.ca/winer. This is an update of the data set first used by Winer and Ferris (2008) which is currently posted. The competition indexes, along with a primary electoral data set based on public data available at the Parliamentary website will be made available at the same site on acceptance of the paper.

\section{Political competition indexes.}

PARTY. The definition of party is important in the calculation of the indexes discussed below, especially in the period before 1945 .

We define a party to be one that has won at least 1 seat in Parliament in at least two elections. From the 105 named parties in the election results this definition yields 13 parties (12 parties plus Other) for our purposes. In addition, we take a broad approach to party labels, including as a Liberal or as a Conservative, the two dominant parties in Canadian electoral history, the small parties that voted almost always with one of these major parties. This broad definition of Liberal and Conservative is the usual approach in the literature. The online data base (available on acceptance of the paper) contains more detail concerning the implications of the choice of the definition of a party.

VOLATILITY = volatility of party vote share across adjacent elections.

Because the size of a winning vote margin is meaningful only in relation to the volatility of the constituency's vote margin, a measure of vote volatility over time is needed. To avoid the considerable loss of information that would otherwise occur when new constituencies were added or old ones redistricted (and hence have no past), we constructed geographically based superconstituencies - 80 in total - based on unchanged geographic regions that persist throughout Canada's election history. For some election years, many of these superconstituencies are not active, such as Newfoundland before 1949. As another example: for Toronto Center superconstituency in election 25 (1945), there are 3 constituencies each with about 50000 electors, while in election 42 (2015), there are 5 constituencies in this superconstituency, each with about 70000 electors. This superconstituency construct allows us to establish regional-specific vote volatilities for use in places and periods when a new constituency was created or an old one redistricted.

A superconstituency volatility is computed as follows. First the vote shares by party over all constituencies within a superconstituency are computed. Next the absolute value of the changes in these (party-specific) average vote shares across adjacent elections are computed, summed and divided by 2 . More formally,

$$
\text { Volatility }_{j t}=\frac{\sum_{p=1}^{13}\left|\bar{v}_{p j t}-\bar{v}_{p j t-1}\right|}{2}, \forall j=1 \ldots 80,
$$

where for each super-constituency, $\bar{v}_{p j t}$ is the average vote share of the $p=1 . .13$ parties (12 plus other) across all constituencies in super-constituency $\mathrm{j}$, in election $t$. Note that volatility is defined using vote shares by party.

Each election specific superconstituency volatility is assumed to apply to each constituency in the same superconstituency. Average aggregate volatility is the vote weighted sum across all superconstituencies.

LNSEATS $=$ Log of the percent of seats held by the governing party in Parliament.

AMCons = asymmetry adjusted marginal constituencies or seats of parties represented in Parliament.

This is a measure of competitiveness among parties at the national level. To operationalize the idea that electoral competitiveness depends on the proportion of asymmetry adjusted marginal constituencies or seats, we must define what marginal means. Let the historical volatility adjusted winning margin for incumbent party $p$ (which won at time $t-1$ ) in constituency $j$ in election $t$ in a given state be defined as

$$
I_{\text {Pmargin }} \text { mit }=\frac{\left(v_{1 p j t-1}-v_{2 j t-1}\right)}{\text { Volatility }_{t-1}},
$$


where $v_{p j t}$ is a vote share for party $p$ in constituency $j$ in election $t$. Here we are defining incumbency by party, not by name of candidate, as with volatility. (At issue is party competition.) Forming a distribution of all IPmargins across a rolling average of three past consecutive elections, and applying a one standard deviation cut-off rule leads to the number and hence proportion of constituencies or seats in the upper tail that are considered safe in each election, $\psi_{t}$. We then compute the proportion of marginal seats in each election, $M S_{t}=$ $1-\psi_{t}$, as a measure of the competitiveness of the election as a whole. MS $=1$ indicates that all of the seats in the state assembly are marginal and hence that the electoral system is highly competitive in this sense. Note that the judgement about whether a seat is marginal or safe depends on historical data only, not on the ex post outcome of an election.

While a smaller overall proportion of safe seats implies that more seats are up for grabs, how safe seats are distributed among competing parties also matters; parties with a preponderance of safe seats have an advantage vis a vis their opposition at least because it can target its resources more narrowly. Adjusting the proportion of marginal seats $M S_{t}$ by the degree of asymmetry among parties in their holding of safe seats produces a new measure of electoral competitiveness at the state level. To do so, we first measure the Euclidean deviation from a three-party equal sharing of safe seats, $\phi 3_{t}$, to reflect the degree to which the distribution of safe seats departs from the case where safe seats are equally distributed, where the third party is a residual consisting of the parties other than the top two:

$$
\phi 3_{t}=\sqrt{3 / 2} * \sqrt{\left(1 / 3-S_{1 t}\right)^{2}+\left(1 / 3-S_{2 t}\right)^{2}+\left(1 / 3-S_{3 t}\right)^{2}} .
$$

Here $S_{p k t}=$ the seat share in the state legislature of the party in kth place in terms of seats. If the safe seats are symmetrically distributed, $\phi 3_{t}=0$, and if one party has all safe seats, $\phi 3_{t}=1$. The computation of the asymmetry adjusted index of marginal constituencies is completed by first adjusting the proportion of safe seats for the asymmetry in their distribution: $A S_{t}=\psi_{t} \phi 3_{t}$, so that $A S_{t}=0$ if safe seats symmetrically distributed, and $A S_{t}=\psi_{t}$ (the proportion of safe seats) if one party has all the safe seats. We then use $A S_{t}$ to define the asymmetry adjusted index of marginal constituencies as $A M$ Cons $_{t}=1-\left\{\psi_{t} \phi 3_{t}\right\}$. Hence $A M$ Cons $_{t}=1$ if all safe seats are symmetrically distributed, and AMCons $_{t}=1-\psi_{t}$, the proportion of marginal seats or constituencies, if one party has all the safe seats. See Ferris, Winer and Grofman (2016) for further details.

Adj_AMCons = AMCons adjusted for redistricting and the addition of brand new constituencies.

Since redistricting and the appearance of new constituencies were frequent in Canada's electoral history, from time to time large numbers of constituencies have no past history and hence there is no clear basis upon which to judge its safeness for the incumbent party. However, because new constituencies will be formed out of constituencies that were previously safe, we judge the the safeness of these new constituencies (at the aggregate level) as follows. Rather than simply treating all redistributed or otherwise new constituencies (that have no incumbent by definition) as marginal, the set of redistributed and new constituencies as a group are treated as being safe, or marginal, in the same proportions as are the set of current constituencies with a past. The proportion of marginal seats or constituencies in each election, Adj_AMCons, is then the sum of the proportion of seats with a past that are judged to be marginal, plus the set of new constituencies without a past that are judged to be marginal. Without this adjustment, the proportion of marginal seats would be just the first part of this sum.

CV_winmargin = the coefficient of variation (mean divided by standard deviation) of the volatility adjusted first versus second place winning vote share margins for the constituencies won by the governing party following election $\mathrm{t}$.

The volatility adjusted, first versus second place win margin for constituency $j$ in election $t$ is: $\frac{\left(v_{1 j t}-v_{2 j t}\right)}{\text { volatility }_{t}}$. The c.v. of the distribution of these volatility adjusted margins is used as a measure of the heterogeneity of electoral pressures facing elected members of the governing party. 
PS_Hist_Cons = the weighted sum of the volatility adjusted vote share margins that each party must overcome at the constituency level relative to the incumbent winning party.

This is a multi-candidate measure of competitiveness among candidates at the constituency level. To avoid the loss of data arising from acclamations and redistricting, the following conventions were adopted. Party candidates winning by acclamation were given a vote-share of 1 and are awarded the national constituency average number of votes to weigh their significance relative to other constituencies. This results in a larger adjusted national vote as the new base for the calculation of adjusted constituency vote shares.

For non-acclaimed constituencies, the vote deficit of each competing party, $h_{p j}^{t}=\frac{\left(v_{1 j t-1}-v_{p j t-1}\right)}{\text { Volatility }_{p t-1}}$, is used to define a constituency specific party competitive index for each party $p, c_{p j}^{t}$, where $c_{p j}^{t}=\left\{\begin{array}{c}1 \text { if } 0 \leq h_{p j}^{t} \leq 1 \\ \frac{1}{h_{j}^{t}} \text { if } h_{p j}^{t}>1\end{array}\right.$.

Redistributions are handled by creating pseudo predecessor constituencies using the average vote shares of those parties in the constituencies (within the same superconstituency) that had been lost due to the redistricting in the above formulas. If the constituency was entirely new (no old constituencies were lost), the previous superconstituency average was used, and if the superconstituency itself was 'newly populated' (as in the case of Newfoundland from 1949), the national average was used. Note again that only historical data is used to construct the current index value for any constituency.

The $c_{p j}^{t}$ 's are then aggregated across all nonwinning parties in each constituency as $C_{j}^{t}=\sum_{p=1}^{P} c_{p j}^{t} v_{p j t}$, and then aggregated across constituencies for each election to get $P S_{-}$Hist_Cons $=\sum_{j=1}^{J} C_{j}^{t} \cdot a d j_{j t}$, where the weights $a d j_{j t}=$ votes in constituency $j /$ total votes at $t$. This multi-party index of competitiveness at the constituency level runs between 0 and 1 with higher values indicating a more competitive constituency.

A note regarding interpolation: When converting a series on elections from an electoral to an annual basis, elections held in the first half of a calendar year were assigned to the previous year to allow for pre-election effects. The competition in the House variables - LNSEATS and CV_winmargin - are held constant between elections since they represent conditions applying during the life of the corresponding Parliament. Adj_AMCons and PS_Hist_Cons are treated as snapshot pictures of an evolving degree of competitiveness and so are interpolated between election years.

For more detail concerning the data described above, see Przeworski and Sprague (1971) and the accompanying web site https://carleton.ca/winer (once the data is posted).

\section{Economic and other variables.}

$D()=$. first different operator; $\operatorname{LN}()=$. logarithm indicator.

AGRIC = percentage of the labor force in agriculture 1870-1925; M.C. Urquhart (1993) Gross National Product, Derivation of Estimates, p. 24; 1926-1975 Cansim D31251/D31252; 1975-2015 Cansim II v2710106/v2710104.

IMRATIO = immigration/POP. Immigration: 18701953 O.J. Firestone Canadas Economic Development 1867-1953 Table 83, Population, Families, Births, Deaths (in thousands); 1954-1995; Cansim D27; 1996-2015 Cansim II v16.

YOUNG = percentage of the population 16/17 and younger; 1870-1920, Lacey et al. (1983) interpolated from census figures Table A28-45 sum of columns 29, 30, 31, and 32, all divided by 28; 1921-1970 Cansim C892547; 1971-2015 Cansim II v466965. 
EXPORTS and IMPORTS = 1929-1960, Leacy (1983), Series G383, 384; 1960-1995, CANSIM series D14833 \& D14836; 1996-2014, CANSIM II v647592. LNGSIZE $=\log ($ GSIZE $)=\log [($ noninterest federal government spending)/GDP]. Interest is on debt privately held.

LNTSIZE $=\log ($ federal government revenues/GDP $)$

LNOPEN $=\log [($ Export+lmports $) / G D P] ; P O P=$ population

LNRGDPPC $=\log ($ RGDPPC $)$ where RDGPPC $=($ GDP $/($ GDPdeflator $* P O P))$

LNDEFICIT $\equiv$ LNGSIZE - LNTSIZE

DEBT = Federal Government Debt; Cansim II number, V151537 (only through 2008).

LNDEBT $=\log ($ Federal government debt as a percentage of GDP $)$

FCOST $=\mathrm{D}(\mathrm{LNRGDPPC})-\mathrm{LR}$ real rate of interest (5yr Gov't bond rate $-\mathrm{D}(\mathrm{LNP}))$

WW1 = 1 in the years $1914-1918,0$ otherwise;

WW2 = 1 in the years 1939 to 1945,0 otherwise.

D1920(30)(42)(46)(74) = 1 in year 1920(1930)(1942)(1946)(19740); 0 otherwise. 
Table A1

Correlations among Political Competition Measures, 1870-2015

Adj_AMCons LNSEATS PS_Hist_Cons CV_winmargin (gov_party)

\begin{tabular}{|c|c|c|c|c|}
\hline Adj_AMCons & 1.000000 & 0.168486 & 0.601930 & 0.294855 \\
\hline LNSEATS & 0.168486 & 1.000000 & 0.168486 & 0.054271 \\
\hline PS_Hist_Cons & 0.601930 & 0.288991 & 1.000000 & 0.230204 \\
\hline CV_winmargin & 0.294855 & 0.054271 & 0.230204 & 1.000000 \\
\hline
\end{tabular}

Table A2

Descriptive Statistics for Canada, 1870 - 2015

\begin{tabular}{|c|c|c|c|c|c|}
\hline Variable & Mean & Maximum & Minimum & $\begin{array}{c}\text { Standard } \\
\text { deviation }\end{array}$ & $\begin{array}{c}\text { ADF statistic } \\
\text { Level-constant (Difference) }\end{array}$ \\
\hline LNGSIZE & 2.273 & 3.767 & 1.251 & 0.597 & $-1.836\left(-7.58^{* * *}\right)$ \\
\hline LNTSIZE & 2.357 & 3.242 & 1.524 & 0.517 & $-1.551\left(-7.65^{* * *}\right)$ \\
\hline LNDEFICIT & -0.084 & 0.632 & -0.663 & 0.252 & $-7.85^{* * *}$ \\
\hline LNDEBTSIZE (2008) & 3.85 & 4.99 & 2.91 & 0.382 & $-3.20^{* *}$ \\
\hline FCOST & 0.05 & 17.79 & -27.55 & 7.15 & $-7.22^{* * *}$ \\
\hline LNSEATS & 4.065 & 4.363 & 3.696 & 0.155 & $-4.967^{* * *}$ \\
\hline Adj_AMCons_SD & 0.847 & 1.00 & 0.594 & 0.151 & $-6.42^{* * *}$ \\
\hline CV_winmargin & 1.80 & 7.43 & 0.716 & 1.62 & $-1.94\left(-10.44^{* * *}\right)$ \\
\hline PS_Hist_Cons & 0.657 & 0.885 & 0.414 & 0.108 & $-6.90^{* * *}$ \\
\hline LNAGRIC & 2.704 & 4.016 & 0.545 & 1.163 & $1.83\left(-8.107^{* * *}\right.$ trend) \\
\hline LNIMRATIO & -0.300 & 1.659 & -2.679 & 0.865 & $-2.54\left(-10.07^{* * *}\right)$ \\
\hline LNOPEN & 3.815 & 4.448 & 3.430 & 0.244 & $-1.949\left(-9.08^{* * *}\right)$ \\
\hline LNRGDPPC & 8.917 & 10.257 & 7.395 & 0.862 & $-0.704\left(-9.030^{* * *}\right)$ \\
\hline GROWTH_RATE & 0.020 & 0.145 & -0.134 & 0.049 & -9.030 \\
\hline
\end{tabular}

Notes: MacKinnon critical $1 \%$ value =-3.48; Probability of not having a unit root at $1 \%(5 \%)[10 \%],{ }^{* * *}\left({ }^{* *}\right)[*]$

Note that LNSEATS and CV_winmargin change discretely at each election interval, while Adj_AMCons_SD and PS_Hist_Cons are interpolated between elections to reflect the ever-changing intensity of their form of political competition between the snapshot pictures captured at the time of each election. 


\section{References}

Aldrich, J. H., and D. W. Rohde (2000). "The consequences of party organization in the House: The role of the majority and minority parties in conditional party government." Polarized politics: Congress and the president in a partisan era: 31-72.

Aldrich, J. H., Rohde, D. W., \& Tofias, M. W. (2007). One D is not enough: Measuring conditional party government, 1887-2002. In D. Brady \& M. McCubbins (Eds.), Party, process, and political change in congress: Vol. 2. Further new perspectives on the history of Congress (pp. 102-112). Stanford: Stanford University Press.

Ashworth, J., B. Geys, B. Heyndels and F. Wille (2014). "Competition in the political area and local government performance" Applied Economics 46(19): 2264-2276.

Bender, B. (1994). "A re-examination of the principal-agent relationship in politics" Journal of Public Economics 53: 149-163.

Besley, T., T. Persson, and D. Sturm (2010). "Political Competition, Policy and Growth: Theory and Evidence from the United States". Review of Economic Studies 77, 1329-1352.

Bohn, H. (1998). "The behavior of U.S. public debt and deficits" Quarterly Journal of Economics 113(3): 949-63.

Borcherding, T.E. (1985). "The causes of government expenditure growth: A survey of the U.S. evidence", Journal of Public Economics 28(3), 359-382.

Borcherding, T.E., J.S. Ferris, and A. Garzoni (2004). "Changes in the Real Size of Government Since 1970", in J. Backhaus and R. Wagner (eds.), Kluwer Handbook in Public Finance New York: Kluwer Academic Press, 77-108.

Buchanan, J. and G. Tullock (1962). The calculus of consent: logical foundations of constitutional democracy. Ann Arbor: University of Michigan Press.

Bueno de Mesquita, B., A. Smith, R.M. Siverson, and J.D. Morrow (2008). The Logic of Political Survival. Cambridge, Ma: MIT Press.

Cox, G.W. and B.R. Weingast (2017). "Executive constraint, political stability and economic growth", Comparative Political Studies. Forthcoming; online at https://doi.org/10.1177/0010414017710254.

Cukierman, A. and A.H. Meltzer (1989). "A political theory of government debt and deficits in a neoRicardian framework", American Economic Review 79: 713-732.

Demsetz, H. (1968). “Why regulate utilities?" Journal of Law and Economics 11(1): 55-65.

Ferris, J.S., Park, S.B. and S. Winer 2008 "Studying the Role of Political Competition in the Evolution of Government Size over Long Horizons", Public Choice 137(1-2): 369-401.

Ferris, J.S. and M. Voia (2018). "Political Parties in Canada: What determines the entry, exit and the duration of their lives", Political Parties (in press).

Ferris, J.S. and M. Voia (2017). "Is the aggregate size of government in Canada too large?" Journal of Institutional and Theoretical Economics 173(4): 723-52.

Ferris, J.S. and E. West (1996). "Testing Theories of Real Government Size: U.S. Experience, 1959 - 1989," Southern Economic Journal 62: 537-553,

Ferris, J.S., Winer, S.L. and B. Grofman (2012). "Do departures from democratic accountability compromise the stability of public finances? Keynesianism, central banking, and minority governments in the Canadian system of party government, 1867-2009" Constitutional Political Economy 23(3): 213-243.

Ferris, J.S., Winer, S.L. and B. Grofman (2016). "The Duverger-Demsetz Perspective on Electoral Competitiveness and Fragmentation: with application to the Canadian Parliamentary System, 1867 - 2011" in M. Gallego and N. Schofield (eds.), The Political Economy of Social Choices, New York: Springer Publishing. 
Holbrook, T. and E. Van Dunk (1993). "Electoral competition in the American States", The American Political Science Review 87: 955-962.

Higgs, R., 1989, "Do legislators, votes reflect constituency preference? A simple way to evaluate the Senate", Public Choice 63(2): 175-181.

Jung, G., L. Kenny and J. Lott (1994). "An Explanation for Why Senators from the Same State Vote Differently So Frequently" Journal of Public Economics 54(1): 65-96.

Kau, J. B. and P.H. Rubin (1981). "The Size of Government", Public Choice 37: 261-74.

Kneebone, R. and K. McKenzie (1999). Past (in)Discretions: Canadian Federal and Provincial Policy, Toronto: University of Toronto Press

Lizzeri, A. and N. Persico (2005). "A Drawback of Electoral Competition", Journal of the European Economic Association, 3(6): 1318-1348.

Mueller, D. (1986). "Interest groups and the size of governments", Public Choice 48(2): 125-145.

Morrow, J.D., B. Bueno de Mesquita, R.M Siverson and A. Smith (2008). "Retesting Selectorate Theory: Separating the Effects of W from other elements of Democracy" American Political Science Review, 102: 393-400.

Palmer, M.S.R. (1995). "Towards an Economics of Comparative Political Organization: Examining Ministerial Responsibility", Journal of Law, Economics, and Organization 7(1): 164-188.

Payne J.E. and B.T. Ewing (1996). "International evidence on Wagner's hypothesis: A cointegration analysis", Public Finance 51(2): 258-274.

Persson, T., G. Roland, and G. Tabellini (2000). "Comparative Politics and Public Finance" Journal of Political Economy 108(6): 1121-1161.

Pesaran, M.H., Y. Shin and R.J. Smith (2001). "Bounds Testing Approaches to the Analysis of Level Relationships." Journal of Applied Econometrics 16(3): 289-326.

Przeworski, A. and J. Sprague (1971). "Concepts in Search of an Explicit Formulation: A Study in Measurement." Midwest Journal of Political Science 15(2): 183-218.

Rodrik, D. (1998). “Do more open economies have bigger governments?" Journal of Political Economy 106: 997-1032.

Rogers, D. and J. Rogers (2000). "Political competition and state government size: do tighter elections produce looser budgets?" Public Choice 105: 1-21.

Salsman, R.M. (2017). The Political Economy of Public Debt Northampton, MA: Edward Elgar Publishing

Sato, M. (2003). "Tax competition, rent-seeking and fiscal decentralization" European Economic Review 47(1): 19-40.

Skilling, D. and R.J. Zeckhauser (2002) "Political competition and debt trajectories in Japan and the OECD" Japan and the World Economy 14: 121-135.

Tullock, G. (1959). "Problems of majority voting," Journal of Political Economy 67: 571-579.

Winer, S. L., M. W. Tofias, B. Grofman and J. H Aldrich (2008). "Trending economic factors and the structure of Congress in the Growth of Government, 1930-2002". Public Choice 135: 415-448.

Winer, S.L. and J.S. Ferris (2008). "Searching for Keynesianism." European Journal of Political Economy, 24(2): 294-316.

Winer, S. L., L. Kenny and B. Grofman (2014). "Explaining Variation in the Competitiveness of U.S. Senate Elections, 1922-2004." Public Choice 161(3-4): 471-497.

Wittman, D. (1989). "Why Democracies Produce Efficient Results", Journal of Political Economy 97(6): 1395-1424. 